\title{
Rusûhî'nin Kuş Diliyle Bir Gazeli ve Yûsuf Sinânüddîn ile Münîrî̀nin Şaire Reddiyesi
}

\author{
Oğuzhan Şahin*
}

Rusubi's A Ghazal in the Paradoxical Sufi Words and Yusuf Sinan al-Din and Muniris Refutation Against the Poet

Abstract — Rusûhî, a Sufi poet, wrote a ghazal in a paradoxical Sufi idiom (kuş dili) in order to show his talent, gain prestige, and demonstrate his knowledge and wisdom. Since this ghazal appeared to be contrary to religious dogma, it caused trouble. Rusûhî, therefore, was accused of blasphemy and was asked to repent. However, Rusûhî did not step back and wrote a letter in defense of his poetry. In the letter, he claimed that it was not his mistake, but rather that of the ulema in interpreting the content at face value. He elicited strong reactions from his own circles. Yusuf Sinan al-din, a fellow Sufi, wrote a refutation to ensure that the poet received the punishment he deserved. Both Rusûhî’s letter and the ghazal itself were severely criticized in Yusuf's refutation. Following a respite in this tension, another refutation,written by Muniri for Rusûhî, appeared. In this epistle, Muniri efendi provided support for Rusûhîs letter in which he defended himself,and offered an explication and interpretation of the ghazal, and finally attempted a refutation of the claims of the Sufi poet Yusuf. This study aims to observe closely a polemic that was triggered by a ghazal.

Keywords: Tadlîl al-Tảvîl, Rusûhî Süleymân, Yûsuf Sinânüddîn, Münîrî-yi Belgradî, ghazal, refutation, heretic and heresy

\section{Giriş}

Günümüzde halkın başucu kitaplarından Mesnevî ile tavsiyeli hikâyelerden Kelîle ve Dimne, bir zamanların yasaklı kitaplarındandır. Bunlara İbn Arabîden Füsûs ile Fazlullâh-1 Esterâbâdî̀den Câvidân ve daha niceleri ilave edilebilir. Genel anlamda söylenecek olursa bu tür eserlerin kara listeye alınma sebebi dine ve

\footnotetext{
* İzmir Kâtip Çelebi Üniversitesi.
} 
mukaddesata karşı küfür ihtiva ettiklerinin düşünülmesidir. Küfre bulaşmak deyince her zaman akla mukaddesata karşı doğrudan bir saldırı gelmemelidir. Bazen şairlerin dolaylı yollardan da olsa bu tür suçlamalarla karşılaşması mümkündür. Yapılan teşbih, telmih ve kıyaslar şairin kastı dışında olsa bile sözü farklı bağlama taşıyıp sahibini zor durumda bırakabilir. Söz gelişi, Şeyhülislâm Yahyâ bir gazelinin matla'inda mescittekileri riyakâr, meyhanedekileri ise pak olarak tavsif edince Kadızâdelilerden Çavuşoğlu adlı bir vâizin hücumuna uğramış ve kâfirlikle suçlanmıştır. ${ }^{1}$ Vâiz Çavuşoğlu'na göre ümmet-i Muhammed'den her kim bu beyti okursa kâfir olur, zira bu beyit küfürdür. ${ }^{2}$ Şeyhülislâmı tekfir edecek kadar katı bir anlayışa sahip bu türden meşâyih ve fakılar, divanlarda "zâhid" tiplemesi ile somutlaştırılmış ki bu tipin en bariz özellikleri taş yürekli olması, riyakârlı̆̆ı, fitne ve nifak çıkarması, dinî hükümleri yüzeysel bir tarzda yorumlaması, halka mey ve mahbubu yasaklamasına rağmen kendisinin gizlice bu fiillerle uğraşmasıdır. ${ }^{3}$ Bazı sûfî şairlere yöneltilen "zendeka ve ilhâd" araladığı göz önüne alınırsa, tasavvufî remizlerle örülü metinlerin, bilhassa da şathiyelerin, tevillerinin neden önemli olduğu anlaşlacaktır. Zira bu tür metinler -sûfî şairlerin savunmacı anlayışı ile söylenecek olursa- kışrına (zâhirine) göre şerh ü tefsir edilirse dinî akîdelerle alay eden, en azından onları hafife alan metinler olarak gözükecektir. ${ }^{4}$ Bu sebeple kuş dilini anlamayandan şathiyelerin uzak tutulması sırrın yabana faş edilmemesi bağlamında kıymet kazanmaktadır. Bu noktada İdrîs-i Muhtefînin "İ̧̧bu deme erince üç kez doğdum anadan” mısrasıyla başlayan meşhur nutkunu Pamukçu el-Hâc Hasan Ağazâde için şerh eden Nakşî şeyhi La 'î̀ Şermî Efendi'nin, Hasan Ağazâde'den, şerh ettiği bu nutku nâ-ehle göstermemesi için ricada bulunması kuş dilini bilmeyen zahir ehlinin bu tür metinlerin kadrini

1 Söz konusu beyit şudur: Mescidde riyâ-pîşeler etsin ko riyâyı / Meyhâneye gel kim ne riyâ var ne mürâyî. Bkz. Rekin Ertem, Yahyâ Divan, (Ankara: Akçağ Yay., 1995), (G. nu. 431/1), s. 240.

2 Hüseyin G. Yurdaydın, "Düşünce ve Bilim Tarihi (1600-1839)” Türkiye Tarihi 3: Osmanlı Devleti (1600-1908), (İstanbul: Cem Yayınevi, 1997), s. 279.

3 Bu konuda daha geniş bir tasvir için bkz. Ahmet Atilla Şentürk, Klasik Osmanlı Edebiyatı Tiplerinden Sûfî yahut Zâhid Hakkında, (İstanbul: Enderun Kitabevi, 1996).

4 Bu yazıda genelde birbiri yerine kullanılan sûfî ve zâhid kavramları eş anlamlı olarak birbiri yerine kullanılmış değildir. Zâhid ile genelde zâhid-i bârid denilen ve divanlarda sûfî şairlerin bile dert yandığı zahir uleması (ulemâ-yı kışrî) kast edilmiştir ki bu tip genelde ham/kaba sofu olarak tasvir edilir. Sûfi ile ise genelde dergâhları mekân tutan gerek tahkik gerekse taklid ehli her türden tasavvuf erbabı kast edilmiştir. Bu kavramlar için bkz. Ethem Cebecioğlu, "Sûfî", "Zâhid-i Bârid”, Tasavvuf Terimleri ve Deyimleri Sözlüğü, (İstanbul: Ağaç Yay., 2009), s. 581, 718; Ahmet Talat Onay, "Zâhid”, Eski Türk Edebiyatında Mazmunlar, nşr. Cemal Kurnaz, (İstanbul: MEB Yay., 1996), s. 506. 
anlayamayacağına binaen olsa gerektir. ${ }^{5}$ Ancak Kadızâdelilerle doruk noktasına ulaşan bu katı anlayış her daim "zındıklık" ve "zâhidlik" gibi karşılıklı ithamlarla ilerlemiş değildir. Şer î akideleri ve şiiri (şathiyeleri) birbirine karşı muhalefet aracı olarak kullananların yanı sıra, vaziyetin kırılganlığının farkında oldukları için sağduyuyla hareket edenler de mevcuttur. Bu bağlamda Azîz Mahmûd Hüdâyî ve Hüseyin Lâmekânî, ulemadan Münîrî-i Belgradî̀ye mektuplar göndererek "cehele-yi mutasavvıfadan ba'zılarının ahvâlini bu tâiife-yi âliyenin umûmına mal etmenin muvâfık-1 akl u insâf olamayacağı" hususunu vurgulamaktadır. ${ }^{6}$

\section{Bir gazelin etrafinda kopan kıyamet}

Abdülbaki Gölpınarlı’nın aktardığına göre h.983 (1575)'te ismi meçhul bir kişi tarafından gizli gencin lüllü-i lâlâsıyam/şöhre-yi aşkem cihan kâlâsıyam beytiyle başlayan bir gazel yazılıyor. Şairinin aleyhine İstanbul günlerce çalkalanıyor. Şaire en sert tepkiyi ise Sünbüliyye şeyhlerinden Yûsuf Sinânüddîn Efendi gösteriyor. ${ }^{7}$ Yûsuf Sinânüddîn, bu gazeli cerh niyetiyle h.983'te Tadlîlü't-Tévîl adıyla bir risale kaleme alıyor.

Tespit edilebildiği kadarıyla, Rusûhînnin bu gazeli şairin kendisi de dahil olmak üzere, üç kişi tarafından ele alınmıştır. İlk önce Rusûhî kendi gazelini, hem bu alandaki maharetini gösterme hem prestij sağlama ve hem de oluşan olumsuz havadan etkilenmeme adına şerh ü tevil etmiştir. İkinci olarak gerek gazele gerekse Rusûhînnin teviline şiddetle karşı çıan Yûsuf Sinânüddîn Efendi sahnede yerini almıştır. Son olarak ise bu işi kendine vazife edinen Münîrî-yi Belgradî olmuştur. Belgradî tıpkı Yûsuf Sinânüddîn gibi bu konuda bir risale kaleme almıştır. Bu üç kişiden ilk ikisi olayın doğrudan muhatabı iken Münîrî Efendi bu hesaplaşmanın doğrudan içinde olmaması ve ilgili risalesini olayın vukû‘undan yaklaşık çeyrek asır sonra kaleme alması nedeniyle tarafımızca dolaylı muhatap olarak düşünülmüştür.

Bir şairin akıbetini iki risale ışığında sürmeye çalışan bu yazının şablonu basitçe şöyledir:

1) Meçhul şair olarak tavsif edilen Rusûhî̉nin kimliğinin tespiti

2) Rusûhî ile Yûsuf Sinânüddîn Efendi hesaplaşması

5 Bahsi geçen durum şerhte şöyle aktarılmıştır: "Mûmâ ileyh Hasan Ağazâde birâderümüzden dahı iltimâs olınur ki nâ-ehle gösterüp nâ-gâh tezyîfden ihtirâz buyuralar.” La'lî Şermî en-Nakşbendî, Şerh-i Nutk-ı Hazret-i İdrîs-i Mubtefì, Milli Ktp. 06 Mil Yz B 169, vr. 3 a.

6 Bursalı Mehmed Tahir, Osmanlı Müellifleri, c. II, nşr. Cemal Kurnaz-Mustafa Tatcı, (Ankara: Bizim Büro Yay., 2009), s. 25-26.

7 Abdülbaki Gölpınarlı, Melâmîlik ve Melâmîler, 5 Baskı, (İstanbul: Milenyum Yay., 2013), s. 74-75. 
3) Münîrî-yi Belgradînnin Rusûhî ve gazeline dair risalesi

4) Rusûhînnin kendini ve gazelini savunduğu mektubun metni

\subsection{Olayın doğrudan muhatabı: Rusûhî Süleymân Efendi (ö. ?)}

Rusûhî̀ye dair en kapsamlı bilgiler Âşık Çelebi ve Kınalızâde Hasan Çelebi tezkirelerinde bulunmaktadır. Üstün bir şairlik yeteneğinin olmaması sebebiyle olsa gerek kendisine dair bilgiler sathî mahiyettedir. Bahsi geçen tezkireler tam künyesinden bahsetmese de adının Süleymân, doğum yerinin ise Sofya olduğunda ittifak halindedir. İlk zamanlar tarîk-1 ilme sülûk ettiyse de sonraları Sofyalı Bâlî Efendi'ye intisap ederek sûfîler kervanına katılmıştır. Sofya'dan İstanbul'a geldikten sonra çeşitli cami ve mahfillerde halka va'z u nasîhat eylemiş, hadis ve tefsir üzerindeki derin bilgisi ile halkın ve devlet erkânının dikkatini çekmiştir. ${ }^{8}$ Rusûhînnin tabakatına dair bu noktalarda bir bulanıklık yoktur. Ancak buradan itibaren Âşık Çelebi ve Kınalızâde Hasan Çelebi farklı bilgiler vermektedir. Kınalızâde’ye göre Rusûhî halk indinde meşhur sûfîlerin sekr hâlinde söyledikleri kelâmı taklid ederek, makamını yüce göstermek istemiş, ancak hâl ehli sûfîlerden olmadığı için kendisinden şeriata muhalif sözler sadır olmuştur. Neticede Rusûhî zındıklık suçlamasından canını firar ederek kurtarmıştır.

Kınalızâde'nin, Rusûhîyi hakiki sûfî kabul etmeyip zendeka ve ilhâd ile suçlamasında ihtimal ki şairin sonradan müslüman oluşu ve doğup büyüdüğü topraklarda rafz u ilhâdın epeyce yaygın oluşu etkilidir. ${ }^{10}$ Çok zayıf da olsa Rusûhî̀nin sonradan müslüman olma ihtimalini doğuran Kınalızâde tezkiresinin [Üniv.Ktp.Ty.nu.1737] nüshasındaki "Sofyalı Bâlî Efendi'nin meşấil-i himmetleriyle ihtidâ olup meslek-i ehl-i irfâna iktifâ..." şeklindeki rivayettir. ${ }^{11}$ Âşık

8 Kınalızâde Hasan Çelebi, Tezkiretü̧ş-Şuarâ, c. I., nşr. İbrahim Kutluk, (Ankara: TTK Basımevi, 1989), s. 407. krş. Aşık Çelebi, Meşấirü̧ş-Şu'arâ, c. III, nşr. Filiz Kılıç, (İstanbul: İstanbul Araştırmaları Enst., 2010), s. 1356. [Bu neşirler bundan sonraki iktibaslarda "Kınalızâde" ve "Âşık Çelebi" isimleri ile gösterilmiştir.]

9 “ol esnâda sâhib-i hâl pûte-yi mücâhedede kâl olmış meşâyihun kîl ü kâline taklîd idüp kendüden zâhir-i şer'-i şerîfe muhâlif küfr-i sarîh ba'z-1 şi r r-i kabîh ve kavl-i vakîh sâdır u zâhir olmış idi. Havf-1 ahzdan kable'l-ahz firâr idüp bi'l-âhare terk-i diyâr eyledi.” Kınalızâde, s. 407.

10 Balkanlarda zendeka ve ilhad için bkz. Ahmet Yaşar Ocak, Osmanlı Toplumunda Zındıklar ve Mülhidler, (15-17. Yüzyzllar), 4. Baskı, (İstanbul: Tarih Vakfı Yurt Yayınları, 2013), s. 343-345.

11 Tezkirenin bu nüshası için bkz. Üniv. Ktp. Ty. nu. 1737; Kınalızâde, s. 407. Bu rivayetle ya Rusûhî̉nin Sofyalı Bâlî̀ye intisapla doğru yolu buluşu yahut gayri-müslimlikten İslâm’a geçişi anlatılmaktadır. Kutluk’un tenkitli neşirde kullandığı diğer iki nüsha [Topkapı, Revan nu.1451; 
Çelebi'nin Kınalızâde ile ters düştüğü nokta Rusûhînnin itikadı ve şeyhliği ile ilgilidir. Kınalızâde’nin riyakârıkla suçladığı Rusûhî yi Âşsk Çelebi hakikat ehli sûfilerden sayar. Tezkire, Rusûhîyi isminden yola çıkarak [adının Süleymân olmasından kinayeyle] onu ins ü cinne hükmeden Süleymân Peygambere benzetir ve bu arada Rusûhînnin cinlere hükmetme gibi bir yeteneğini de dile getirmiş olur. Tezkireye göre Rusûhî, Sofya civarında yaşamış Porenli denen cennet ehli bir tầifeye mensupdur. Rusûhînnin kıymeti hâiz bir diğer yönü ise iyi bir rüya tabircisi oluşudur. Hamzavîlerin rüya ve rüya tabirine gerekli ehemmiyeti vermedikleri düşünülücek olursa Rusûhî ile Hamzavîler bu noktada ayrışmaktadır yahut bir nevi Rusûhî ile Bayramî-Melâmîleri arasına ince bir çizgi çekilmektedir. ${ }^{12}$ Rusûhî̀ yi temize çıkaran unsurlardan birisi de intisap ettiği Sofyalı Bâlî Efendidir. Âşık Çelebi, Rusûhî̉nin Sofyalı Bâlı̂̀ye intisabını hayra atılmış bir adım olarak şu sözlerle dile getirir:

Topkap1, Revan nu.1270] “ihtidâ olup” rivayeti yerine "sâlik-i râh-1 hüdâ olup” şeklinde bir rivayet benimsemiştir. [Milli Ktp.06 Hk 97, vr.119a] ve [Raşid Efendi 934, vr.117b] nüshaları da "sâlik-i râh-1 hüdâ olup" rivayetinde birleşmektedir. Bu durumda "ihtidâ olup" rivayetinin bir müstensih hatası olma ihtimali artmaktadır. Fesâhat bakımından ise ihtidâ "olmak" yardımcı fiiliyle değil "etmek/eylemek" ile kullanılmalı idi. "Olmak”la kullanılması gereken "ihtidâ” değil "mühtedî” dir.

12 “Risâle-i Tầifân-1 Melâhidân” yahut "Eyyühe'l-Veled” isimli risalede Melâmîlerin iddialarını cerh eden Mehmed Amîkî rüyâ meselesine de değinir. Amîkî, risaleyi önceleri kendi müridi olan "Veled" isimli bir sipahizâdenin Hamzavî bir şeyhe [Gölpınarlı’ya göre bu şeyh İdris-i Muhtefîdir. Bkz. Gölpınarlı, s. 76.] intisabı sonrası Hamzavîlerin sapkın fikirlerini çürütmek için kaleme almıştır. Rüya bahsi risalede şu şekilde ele alınmaktadır: "Eyyühe’l-veled istimâ‘ olındı ki tâbi" olduğun 'azîz rü'yâya ve 'ilm-i ta'bîre inkâr ider imiş (...) hatâ-yı mahzdur ki Hak celle ve 'alâ Kur'ân-1 'azîmde niçe yirde rü’yâyı isbât buyurur (...)” Mehmed Amîkî, Risâle-i Tầife-i Melâhidân, Milli Ktp, 06 Mil Yz A 330/3, vr. 61b. Fakat ileride bahsi geçecek Emîr Osmân Hâşimî adlı Hamzavî bir zat rüyasında Hz. Ali’yi görür ve Hz. Ali, Emîr Osman’a: “Oğlum Osman, eğer beni istersen Vize’ye gel.” der. Bu rüya üzerine Vize'ye giden Emîr Osman, Gazanfer Dede’ye intisap eder. Bkz. Osmanzâde Hüseyin Vassâf, Sefine-i Evliyâ, c. II, nşr. Mehmet Akkuş-Ali Yılmaz, (İstanbul: Kitabevi, 2011), s. 534; Gölpınarlı, s. 68-69. Rüya bahsine dair Emîr Osmân Hâş̧imî ile ilgili Sefine’de şöyle bir anekdot daha nakledilir: "Nûreddînzâde hazretlerinin fukarâsı her sabâh rü’yâlarını azîzlerine arz etmeleri mu 'tâd olmakla, bu meyânda, Hz. Emîr’ in hiçbir rü’yâ arzı vâki olmaması bâ'is-i taaccüb olmakta iken, bir gece rü’yâsında Fahr-1 âlem (s.a.v.) efendimizi dest-i mübâreklerinde yeşil renkli bir destmâlden üç yapraklı tâze bir ayva çıkarıp Nûreddînzâde’ye veriyorlar, yolundaki müşâhedât üzerine ertesi sabâh [Nûreddînzâde], 'Yâ Emîr, sen hiç rüyâ görmez misin, zîrâ ta 'bîr için hiç mürâca'at etmiyorsun.' buyurunca Hz. Emîr, Cenâb-1 Şeyh’in rüyâda gördügü ü ç yapraklı ayvayı hırkası altından çıkarıp, 'Efendim, işte fakîrinizin rüyâsı.' diye ayvayı takdim eylemiştir. Bunun üzerine 'Ey Emîr, artık senin bize ihtiyâcın kalmadı. İki arslan bir postta olmaz. Var artık kendi postuna sâhib ol.' diye icâzet vermişlerdir. Hüseyin Vassâf, s. 535 . 
“şeyhu'l-mürşidîn muktedâ-yı selef-i sâlihîn meşâyih-1 sûfiyyeden Sofyalı Şeyh Bâlî Halîfe hazretlerinden tevbe vü inâbet itdi. Hakkâ ki tevfîk-1 hayra refîk olup isâbet itdi."13

Sofyalı'ya intisap ederek tövbe alan Rusûhî "mevâlî-yi izâm” hizmetinden feragat etmiş, yani ilmiye sınıfı ile bağını koparıp sûfilere katılmıştır. Geçimini ise vaazlar vererek temin etmektedir. Rusûhînin birtakım isnâdlara maruz kaldığını Kınalızâde'den sonra Âşık Çelebi'den de okuyoruz. Kınalızâde bu isnâdlara sebep olarak Rusûhînnin söylediği şiiri göstermişken, Âşı Çelebi’de bu durum ayrıntılarıyla dile getirilmiş değildir. Ancak Kınalıâde, Rusûhînnin yakalanmadan önce can korkusuyla firar ettiğini yazmasına karşın, Âşık Çelebi şairin birtakım asılsız iddialarla teftişe uğrayıp bir süre hapsedildiğini ve hapisten kurtulunca kalbinin saf bir altına döndüğünü yazıyor. Üstelik Rusûhî hapisten çıkınca da çeşitli mahfillerde irşâd faaliyetlerine devam etmiştir. Demek ki şair akıbeti belli oluncaya kadar hapiste tutulmuş, kendisinde bir zendeka emaresine rastlanmayınca, en azından bu durum kesin bir şekilde ispat edilemeyince serbest bırakılmıştır. ${ }^{14}$ Anlaşılan odur ki Kınalızâde’nin bahsettiği “can korkusuyla firar etme” vakası Rusûhînin son icraatıdır. Âşık Çelebi tezkiresi Rusûhî’nin firarından [firar muhtemelen 1575 ve sonrasında gerçekleşmiş; tezkire ise h.976/1568'de bitirilmiştir] önce bitirildiği için, Rusûhî’nin firarına sebep olacak olayları kaydetmemiştir. O halde Âşık Çelebi'nin bahsettiği ve Rusûhî’nin yargılanmasına sebep olacak başka olaylar söz konusudur yahut Kınalızâde vâiz kimliğiyle büyük patırtılara sebep olan ve canını firar ederek kurtaran bir diğer Bayramî-Melâmî şeyhi İdrîs-i Muhtefî ile Rusûhî̀yi karıştırmaktadır. Gerçi geçimini temin için vâizlik yapmak zorunda kalan Rusûhî ile ticaret erbabı İdrîs-i Muhtefî̀nin [tüccar Hacı Ali Bey yahut Şeyh Aliyy-i Rûmî] vâizlik yapmak ve şiir söylemek dışında pek benzer tarafları yok gibidir. Acaba Hacı Ali Bey adıyla ticaret yapan, Şeyh İdrîs adıyla vaazlar veren İdrîs-i Muhtefî, Rusûhî (Süleymân) ismiyle de İstanbul'da bulunmuş mudur? Yoksa namı Süleymân olan Rusûhî mahlaslı birisi gerçekten o dönemlerde yaşamış mıdır?

Rusûhînin akıbetine dair farklı bir iddia Münîrî-yi Belgradîden gelmiştir. Gazelle ilgili bir risale yazan Münîrî, Kınalızâde’nin firar rivayetine karşın, Rusûhînnin “III. Murad'ın cülûsu (8 Ramazan 982/22 Aralık 1574) evâyilinde zendeka isnâdıyla İstanbul'dan sürgün edildiğini” rivayet etmekte, ancak nereye

13 Âşık Çelebi, s. 1356.

14 Melâmî kutblarından Gazanfer Dede’nin de benzer bir şekilde alıkonulduğu vakidir. Ebussuûd Efendi, Gazanfer Dede’nin durumunu tedkik etmiş ve delilleri yetersiz gördüğü için Gazanfer Dede'nin salıverilmesine icazet vermiştir. bkz. Ocak, s. 359-363. 
gönderildiğine dair bir bilgi vermemektedir. ${ }^{15}$ Bu bağlamda Kınalızâde'nin iddia ettiği üzere Rusûhî firar etmemiş, sürgüne gönderilmiştir.

Rusûhî, Kınalızâde'de bulunmayıp Âşık Çelebi tezkiresinde bulunan birkaç rafz u ilhâd töhmetine daha maruz kalmıştır. Ancak Âşık Çelebi bu iddiaları "mâlem-yekûn” diye tavsif ederek asılsız ve kıymetsiz bulmaktadır. Tezkirecinin düştüğü "yine halâs oldı" kaydına bakılacak olursa Rusûhî zendeka cürmü ile çeşitli kereler teftiş edilip hapsolunmuştur:

"bir zamân dahı ba'z-1 isnâd-1 mâ-lem-yekûn ile müfetteş ü mahbûs olup sicnde sünnet-i Yûsufı riâyet eyledi yine halâs oldı kalb-i hâlisi hulâsadan çıkup zer gibi hâs oldı."16

Yine Âşık Çelebi'nin kayıtlarına göre Rusûhî pâyitahtın “hûb-mesîhî”lerinden Hakîm İshâk tâifesinden birkaç kişinin de hücumuna uğramıştır. ${ }^{17}$ Kendisine hûb-mesîhîlik çamuru atmaya çalışan birkaç nefer bu yolla Rusûhî̀nin katlini amaçlayıp Şeyhülislâm Ebussuûd Efendi huzurunda bu iddialarını ispata çalışmıştır. Neticede hileleri kendi ayaklarına dolanmış ve Tevrat'ın hâlâ sahih olduğu iddiasıyla önceden bir risale yazdığı ortaya çıkan bu tâifenin şeyhi katledilmiştir:

"mevlânâ-yı merkûmun [Rusûhî̉nin] kerâmâtındandur ki Hakîm İshâk dimekle ma' rûf Hakîm İsak tevâbi' inden iki üç nefer-i tâgîler ki bâgîler gibi ehl-i İslâmun katline bâgîlerdür ol fakîrün [Rusûhînnin] bitarîkı'l-ikfâr katline sấ̂̂ler olup imâm-1 hümâm şeyhü'l-islâm hâmî-i şer'-i Nebî aleyhi's-selâm huzûrında müddeâlarına muvâfık istiftâya geldüklerinde şeyhleri olan hücûd-ı cühûd dîninden dönme olmagın Tevrâtun mensûh olması husûsında risâle tahrîr itmiş imiş. Takrîr olınurken içlerinden bir kerîm-nihâd-ı sahîhu'l-itikâdları mâhüve'l-vâkı' tefsîr eyleyüp bu kaziyye Tevrâtda mestûr iken nice mensûh olınabilür ve iyâdı cenâbından nice masûn olur dinilürken kıssa ol zemânda ki Lût kavmi hasf olınup hatunı gâbirînden oldı Lût aleyhi's-selâmun kerîmeleri cümle kâinâtı helâk oldı zannidüp tenâsül munkatı' olmasun hâş̧â ve kellâ Lût Peygamber Hazretlerini hamr ile ser-mest idüp kendülere vikâ‘ itdükleri sebebiyle iki

15 Münîrî-yi Belgradî, Şerh-i Kaside-i Süleyman, Çorum Hasan Paşa İl Halk Ktp. 19 Hk 668/1(a), vr. $5 \mathrm{a}$.

16 Âşı Çelebi, s. 1356. Âşık Çelebi tezkiresinin bir nüshasında "yine halâs oldı" yerine "yine tîzrek halâs oldı" rivayeti kullanılmıştır. Bu durum bir müstensih hatası değilse Rusûhînnin hapiste uzun süreli tutulmadığı anlaşılıyor. Bkz. Âşık Çelebi, Tezkire-yi Şu'arâ, Çorum Hasan Paşa İl Halk Ktp.,19 Hk 1964, vr. 332a.

17 Hakîm İshâk için bkz. Ocak, s. 279-280. 
veled zuhûra gelüp anlar dahı peygamber oldı diyü tastîr olınmışdur diyü nakl eyleyicek kendüler ikfâr olınmışdur teşhîr içün ahşam namâzın kıldukları mescidde 'alâ-mele'i'n-nâs tecdîd-i îmân nikâh buyurılup mezbûr Süleymân Halîfe [Rusûhî] ile husûmete delîl olan Halîl kavm-i Firavn gibi muğrakînden olup şâhidlerün biri kûr ve birinün bir gicede kulı ve câriyesi ve bir atı ve iki re'̂̂s-i bakarı helâk olup alâ-mele'i'n-nâs meşhûr oldı ve biri dahı Süleymân Halîfe yüregüme kızmış mîh sancdı diyürek helâk oldı."18

Kısa süreli tutulduğu hapisler istisna edilirse, biri bahsi geçen Hakîm İshâk taifesi ile vâki hadise olmak üzere, Rusûhî en az iki kez ilhâd suçlamasıyla Ebussuûd Efendi'nin huzurunda kendini müdafaa etmek zorunda kalmıştır. İkinci hadiseye Tadlîlü't-Tevîl konusunda işaret edilecektir.

Rusûhînin kimliğine dair Gölpınarlı tarafından bir tahmin yürütülmüştür. Buna göre bu kişi Emir Osmân Hâşimî’den başkası değildir. ${ }^{19}$ Zira gazelin fırtınalar kopardığı dönemde (h.983) Melâmîlerin başındaki Hasan-1 Kabâdûz’un şairlik yeteneği yoktur, üstelik olay İstanbul'da olurken Hasan-1 Kabâdûz Bursa'da oturmaktadır. O yıllarda İstanbul'da Gazanfer Dede’ye müntesip Emîr Osmân Hâşimî bulunmaktadır. Hâşimînnin aleyhinde de zendeka ve ilhâda dair epeyce dedikodu mevcuttur. Öyle ki Hâşimî bu dedikodular sebebiyle idamdan Nûreddînzâde'ye intisapla kurtulmuştur. ${ }^{20}$

Kınalızâde’nin bahsi geçen gazelden iki beyti Rusûhînnin ebyatına örnek olarak sunması ve Rusûhî adına kayıtlı birkaç kaside ve risalenin kütüphanelerde yer alıyor olması, bu meçhul şairin Emîr Osmân Hâşimî olma ihtimalini epeyce zayıflatıyor. Gölpınarlı, nâmı meçhul diye tavsif ettiği bu şairi Hamzavîler arasında arıyor. Her ne kadar Hamzavîlerin maruz kaldığı zındıklık ve mülhidlik suçlamasıyla hapis yatsa da Rusûhî, Halvetîliğin İstanbul'daki kolu olan Sofyalı Bâlî hânkâhında irşâda devam ediyor. ${ }^{21}$ Gerek Rusûhî gerekse Emîr Osmân Hâşimî̀nin Halvetîliğin aynı koluna intisapları [Rusûhî Sofyalı Bâlî̀ye intisap etmiş ve onun halifelerinden olmuştur. ${ }^{22}$ Hâşimî ise Sofyalı Bâlî̀nin halifelerin-

18 Âşıı Çelebi, s. 1357.

19 Emîr Osmân Hâşimî için bkz. Mustafa Uzun, "Hâşimî Emîr Osmân Efendi”, Türkiye Diyanet Vakfi İslâm Ansiklopedisi (DİA), 1997, c. 16, ss. 411-412.

20 Gölpınarlı, s. 75. Zendeka ve ilhâda bulaştı̆̆ına dair Nureddinzâde' yle ilgili de dedikodular vakidir ve bunlar Ebussuûd Efendi tarafından tezkiye edilmiştir. Bkz. Reşat Öngören, Osmanlılar'da Tasavvuf: Anadoluda Sûfiller, Devlet ve Ulemâ (XVI. Yüzyll), 3. Baskı, (İstanbul: İz Yayıncilık, 2012), s. 353.

21 "Kendü nefsinden gayrı câmi'-i şerîfde şerî‘at-1 kaviyye sa îdlerin ve Bâlî Efendi hânkâhında olan tarîkat-1 sûfiyye mürîdlerin irşâdı ser-berdür.” Âşıłk Çelebi, s. 1357.

22 Rusûhî̀nin Sofyalı Bâlîye intisabını tezkireler yanında Şakâyık da doğrulamaktadır. Sofyalı 
den Nûreddînzâde'ye intisap etmiştir.] ve benzer çizgide şiir söylemeleri bu kişilerin karıştırılmalarında önemli bir etken gibi gözüküyor. Ancak yine de her ikisinin farklı mahlaslar kullanmaları [Rusûhî Süleymân Rusûhî̀yi, Emîr Osmân Hâş̧imî ise Hâşimî̀ yi kullanıyor.] ve memleketlerinin farklı oluşu [Rusûhî Sofyalı, Hâş̧imî ise Sivaslı] bu iki sûfînin tefrikini büyük ölçüde mümkün kılıyor.

Rusûhî̀nin karıştırıldığı isimlerden biri de meşhur Mesnevî şârihi İsmâil Rusûhî-yi Ankaravîdir. Bazı kaynaklarda Rusûhî Süleymân Efendi’nin, Usûlî neşvesiyle yazdığ 1 "Ey ki âlemden haberdârım diyen dünyâ nedirl Bugünün yarmı bilmezsün eger dün yâ nedür" beytiyle başlayan kasidesi sehven Rusûhî Ankaravî̀ye ait gösterilmiştir.

\subsubsection{Rusûhî’nin müellefâtı}

Rusûhî̀nin şiirlerine Kınalızâde ve Âşık Çelebi tezkireleri ile birkaç mecmua dışında tesadüf etmek pek mümkün değildir. Tezkirelere yansıyan Rusûhî portresinde ise onun şairliğinden neredeyse hiç bahsedilmemiştir. Bu sebeple, şair adına tertip edilmiş bir divandan bahsetmek şu an için çok mümkün değildir.

Âşık Çelebi'de Rusûhîye ait mahlashânesi olmayan dört beyitlik bir gazel ve şairleri değerlendirdiği mesnevi nazım şekli ile söylenmiş bir manzume karşımıza çımaktadır. ${ }^{23}$ Kınalızâde'de Rusûhînnin şiirlerine örnek olarak iki farklı gazele ait dört beyit verilmiştir. Bu dört beyitten ikisi bu yazıya konu olan gazele aittir, diğer iki beyit ise Âşık Çelebi’deki gazelin aynısıdır. ${ }^{24}$ Gerek Kınalızâde, gerekse Âşık Çelebi'de geçen:

"Bâğ-1 cân içre dikelden kâmet-i bâlânı sen

Nûrdan bir serv olur her kanda salsam sâye ben"

matlalı bu gazel Ahmed Paşảnın,

"Dün dehânun sırrını sordum mükerrer goncadan

Didi kim yokdur bu râzı açmağa bizde dehen"

Bâlînnin tercüme-yi halinde Rusûhî̀den "Rusûhî Süleymân Halîfe" olarak bahsedilmektedir. Bkz. Mecdî Mehmed Efendi, Hadẩikuşs-Şakâyık, nşr. Abdülkadir Özcan, (İstanbul: Çağrı Yay., 1989), s. 521.

23 Âşık Çelebi, s. 1357-1359.

24 Kınalızâde, s. 407-408. 
matlalı 7 beyitlik gazeline bir naziredir. ${ }^{25}$

Bunların dışında az önce de vurguladığımız "Ey ki âlemden haberdârım diyen dünyâ nedir/ Bugünün yarın bilmezsün eger dün yâ nedür” beytiyle başlayan Rusûhîye ait bir gazel daha mevcuttur. Sûfiyâne bir üslûba sahip bu gazelin, şerh edilmiş olarak kütüphanelerde birçok nüshası bulunmaktadır. ${ }^{26}$ Kanaatimizce Rusûhî̀ye şöhretini kazandıran metinlerin en önde geleni bu gazeldir. Şiirleri dışında Milli Kütüphane’de "Rusûhî Süleymân" adına kayıtlı rafz u ilhâd ile ilgili iki yapraklık bir risale daha göze çarpmaktadır. ${ }^{27}$

\subsection{Olayın diğer muhatabı: Yûsuf Sinânüddîn Efendi (ö.1581) ve risalesi}

Sünbüliyye şeyhlerinden olan Yûsuf Sinânüddîn Efendi (ö.1581) Yanya'da doğmuş, babası Sünbüliyye şeyhlerinden Germiyanlı Yakûb Efendi’nin (ö.1571) İstanbul Davutpaşådaki bir zaviyeye şeyh olarak tayini üzerine dört yaşında İstanbul'a gelmiştir. İstanbul'da zâhirî ilimler tahsilini tamamladıktan sonra bazı medreselerde müderrislik yapmıştır. Şeyh Yakûb Efendi'ye intisap edip ondan icazet almıştır. Babası Şeyh Yakûb Efendi'nin vefatı üzerine Kocamustafapaşa Sünbüliyye Hânkâhı'na şeyh olarak tayin edilmiştir. Padişah III. Murad tarafından şeyhüll-harem olarak Medine'ye gönderilmiş, dört yıl görev yaptıktan sonra burada 1581'de vefat etmiştir. ${ }^{28}$

\subsubsection{Risalenin telif tarihi}

Yûsuf Sinânüddîn Efendi'yi olayın doğrudan muhatabı kılan Rusûhî̉nin gazeline yazdığı Tadlîlü̉t-Tévîl adlı risaledir. Süleymâniye nüshasına göre bu risale [h.983/1575]'te Manisa nüshasına göre ise [h.980/1572-73]'te kaleme alınmıştır. ${ }^{29}$

25 Pervâne b. Abdullâh, Pervâne Bey Mecmuası, c. 3, nşr. Kamil Ali Gıynaş, (İstanbul: Akademik Kitaplar, 2014), s. 157. [zemin şiir nu. 5831; nazire nu. 5858.]

26 Bkz. Şerh-i Kasîde-yi Rusûhî, Milli Ktp., 06 Mil Yz A 2581, vr. 148a-153b; krş. Süleymaniye Ktp., Ali Nihat Tarlan 137, vr. 89b-96b.

27 Bkz. Rusûhî Süleymân, Risâle fî-Hakki’r-Revâfiz, Milli Ktp., 06 Mil Yz A 5221/3, vr. 54a-55b.

28 Nazif Velikahyaoğlu, Sümbüliyye Tarikatı ve Kocamustafapaşa Külliyesi, (İstanbul: Çağrı Yay., 2000), s. 197-198; Hür Mahmud Yücer, "Sünbüliyye”, DİA, 2010, c. 38, s. 137; Öngören, s. 78-79.

29 Yûsuf Sinânüddîn, Tadlîlü̈t-Tèvîl, Süleymaniye Ktp, Esad Ef. nu. 3689, vr. 1b; Manisa İl Halk Ktp., 45 Hk 2912/8, vr. 111b. 
Farklı bu iki kayıt risalenin telif yılı üzerinde de durmayı gerektirmektedir. Esad Efendi nüshasının ferağ kaydına göre, Tadlîlü̈t-Tẻvîle 17 Şevvâl akşamında başlanmış ve aynı günün gece yarısına kadar tamamlanmışır. ${ }^{30} \mathrm{Bu}$ kayıt müellif hattından kopyalandıysa risalenin telif tarihi tam olarak17 Şevval 983 (19 Ocak 1576) olmaktadır. Manisa nüshasında risalenin telif yahut istinsahına dair herhangi bir bilgi bulunmamaktadır. Üstelik bu nüsha diğerine göre ciddî fark ve eksikler içermektedir. Bu yönüyle bu nüshanın rivayeti olan 980 senesinin bir müstensih tasarrufu olduğu fikri ağırlık kazanmaktadır. Tadlîlüt'-Tèvîllde şair Rusûhî̀nin kendi küfrünü tevil için devrin şeyhülislâmı Ebussuûd Efendiden bir fetva aldığı yahut Yûsuf Sinânüddîn'in iddiasıyla söylenecek olursa böyle bir fetva uydurup [muhtemelen fetva tartışmasının yaşandığı zaman Ebussuûd Efendi hayatta değildir] Ebussuûd Efendi'ye iftira ettiği vurgulanmaktadır. ${ }^{31} \mathrm{O}$ halde reddiyeye uğramış bu gazel yazıldığında Ebussuûd Efendi hala hayattadır. Ebussuûd Efendi 5 Cemâziyelevvel 982 (23 Ağustos 1574) tarihinde vefat etmiştir. Şu durumda Rusûhî bu gazeli en geç h.982 (1574) senesi yazında söylemiş olmalıdır ve İstanbul'da büyük yankı uyandıran bu gazele yaklaşık bir buçuk yıl sonra Yûsuf Sinânüddîn tarafından bir reddiye yazılmıştır. Reddiyenin gazelden hemen sonra kaleme alınmayıp aradan belli bir süre geçtiği Tadlîl'deki:

"fi'l-hakîka câdde-yi hakdan mikdâr-1 ser-i mû inhırâf itmez erbâb-1 tab'-1 selîm ve ashâb-1 dîn-i mustakîm olan firka-yı resîdeye lâyık olan bu makûle güftâra mutasaddî olan murdâr u bed-girdârı sengsâr ve yâhud ihrâk bi'n-nâr itdürmek iken müsâmaha vü müsâhelenün sebebi ma'lûmumuz olmadugından cigerümüz hûn ve derûnumuz gumûm u hümûm ile meşhûndur."

şeklindeki kayıtdan anlaşılmaktadır. Buna göre reddiye müellifi dînî akideleri tahfif eden şair Rusûhî̉nin ceza görmeyişini büyük bir üzüntü ile karşılamaktadır. $^{32}$ Görülen o ki Yûsuf Sinânüddîn Efendi büyük yankılar uyandıran gazeli sebebiyle Rusûhînnin tedibini epeyce beklemiş, böyle bir vaziyet göremeyince bu mülhide haddini bildirmenin kendisine düştüğü fikriyle kaleme sarılmıştır.

Münîrî-yi Belgradî tarafindan vurgulanan Rusûhî Süleymân’in, III. Murâd'ın cülusu (22 Aralık 1574) evâyilinde İstanbul'dan sürgün edildiği iddiasına göre, Rusûhî̀nin gazelini yazması, gazelin reddiyeye uğraması ve şairin sürgüne gönde-

30 Esad Ef. nu. 3689, vr. 9a.

31 Esad Ef. nu. 3689 vr. 5a; Manisa nüshası, 45 Hk 2912/8, vr. 114a.

32 Yûsuf Sinânüddîn, Tadlîlü't-Tévîl, Esad Ef. nu. 3689, vr. 7b. [Tadlîlü't-Tévîl'den yapılan alıntılarda bu nüsha kullanılmış ve bu nüsha "Yûsuf Sinânüddîn" ismiyle tesmiye edilmiştir.] 
rilmesi yaklaşık bir buçuk yıl gibi bir sürede cereyan etmiştir. Buradan hareketle olayların sıcağı sıcağına gerçekleştiği söylenebilir. Tadlî̉ in telif tarihi h.980 olduğu kabul edilecek olursa gazelin söylenmesi, reddiyenin yazılması ve sürgüne gönderiliş süreci yaklaşık dört yıl gibi bir süreye yayılacaktır ki bu süre zarfında olayın güncelliğini kaybedip unutulma ihtimali yüksektir. Neticede Rusûhînnin gazelini söylediği yılın h.982 ve Tadlîlǘt-Tévîllin telifinin de h.983 olduğunu kabul etmek akla yatkın gözükmektedir.

\subsection{Reddiyeye uğrayan gazel}

Rusûhînnin bu gazelini yedi beyit şeklinde Münîrî Efendi'nin risalesinde ve iki beyit şeklinde de Kınalızâde tezkiresinde görmekteyiz. ${ }^{33}$ Âşık Çelebi tezkiresinde bu gazelden hiç bahsedilmiyor. Bunun sebebini tezkirenin tamamlandığı tarihten daha sonra gazelin telif edilmesi olarak belirtmiştik. Gölpınarlı eserine gazelin dört beytini kaydetmiş ve bu beyitlerin kaynağını belirtmemiş. ${ }^{34}$ Gölpınarlı'daki beyitler Tadlîlde de mevcut ve Tadlî̉deki beyitlerle Gölpınarlı'nın sunduğu beyitler arasında matla'ın ikinci mısrası dışında fark yok. ${ }^{35}$ Münîrî risalesindeki gazel ile Gölpınarlı ve Tadlîldeki beyitler arasında ise nüsha farkları var. Şu durumda Gölpınarlı, Rusûhî̀nin bu gazelini Tadlîlü̉t-Tẻvîllden iktibas etmiş gibi gözüküyor. Gazelin Münîrî Efendi risalesindeki metni şöyledir:
- - - ' - - - ' - -
Gizlü gencün lü’lü'-i lâlâsıyam
Şöhre-yi şehrem cihân kâlâsıyam
Kıymetüm iki cihâna sığmadı
Kulzüm-i 'işkun dürr-i yektâsıyam
Tifl-1 ebced-hânum olmışdur melek

33 Kınalızâde tezkiresindeki söz konusu beyitler şunlardır: Kûh-1 dehrün merd-i bî-pervâsıyam/ Deyr-i 'ş̧kun hem çelîpâpâsıyam; Her ne dirsem Hakk anı eyler hemân/ Şöyle benzer ben anun agasıyam bkz. Kınalızâde, s. 408.

34 Gölpınarlı’nın iktibas ettiği beyitler şunlardır: Gizlü gencin lü’lü-i lâlâsiyem/ Şöhre-i aşkım cihân kâlâsiyem; Küntü kenzin remzinin Mevlâsiyem/ Zât-1 bahtın alleme'l-esmâsiyem; Mescid-i aşkın imâmı olmuşam/ Deyr-i aşkın hem çelîpâpâsiyem; Ben ne dersem Hak anı işler hemân/ Şöyle benzer ben anın ağasiyem bkz. Gölpınarlı, s. 74 .

35 Gölpınarlı'daki "Şöhre-i aşkım cihân kâlâsiyem” mısrası Tadlîlde "Şöhre-yi şehrem cihân kâlâsiyem” biçiminde. Ayrıca Tadlîlde iki ayrı matla olarak vurgulanan iki beyit Gölpınarlı’da alt alta dizilmiş. bkz. Tadlîl, vr.7b. 
Bir güzeller müftisi monlâsıyam ${ }^{36}$

Anamun karnında anam atası

Oğlumun oğlın emer lâlâsıyam

Mescid-i 'ş̧skun imâmı olmışam

Ehl-i deyrün hem çelîpâpâsıyam

Her ne dirsem Hakk anı eyler hemân

Şöyle benzer ben anun ağasıyam

Ey Rusûhî şem'-i cem'-i 'âlemün

Bâl u per yakmakda bî-pervâsıyam ${ }^{37}$

\subsection{Sûfînin sûfîyle mücadelesi}

Tezkirelerdeki tercüme-yi hâle göre zendeka ve ilhâd isnadıyla hapis yatan Sofyalı Bâlî̉nin halifelerinden Rusûhînnin kendisi gibi medrese kökenli Sünbüliyye şeyhlerinden Yûsuf Sinânüddîn karşısında zor anlar yaşadığı aşikardır. Yûsuf Sinânüddîn Efendi Rusûhîy yi zındıklık, yalancılık, kâl ehlinden olma, makamından öte kelâm etme ve mukallidlik gibi sözlerle tenkit edip cezalandırılmasını talep etmektedir. Bu amaçla yazdığı risalede hamdele ve salvale kısımlarını müteakıben Rusûhîyi tavsifen şu satırları okuyoruz:

"bir dâhiye-yi dehyâ ve musîbet-i dîn ü dünyâ ki gulât-1 mutasaviffadan ve tugât-1 mutasallifeden bir gûl-i nâ-bînâdur zuhûr u bürûz idüp tarîka-yı enîka-yı meşâyihde a'mâ olmağın şerî́at-1 Hazret-i Muhammed Mustafâda [...] bivechinmâ-revâ olmayan nâ-sezâ kelimâtı gûyâ olup beyne'l-avâm işấa vü ifşâ eyledi”’38

Buna göre Rusûhî hakikat ehli bir sûfî değil, insanları dalalete sürükleyen kör bir şeytandır. Tarikatın acemisidir. Bir hünermiş gibi söylediği şeriata muhalif sözleri (şiirleri) sebebiyle fitne çıkarmaktadır. Kelâmının zahiren küfre, tevil edilince ise hakikate taalluk eden yapısı sebebiyle zarâfet ehlinden sayılıp "şâ ir-i

\footnotetext{
36 İkinci tef ilede vezin aksamaktadır.
}

37 Münîrî-yi Belgradî, Şerh-i Kaside-i Süleyman, Çorum Hasan Paşa İl Halk Ktp. 19 Hk 668/1(a), vr. 1b. Bu eserin Milli Ktp. nüshasında altı ve yedinci beyitlerin ikinci mısraları "Şöyle benzerüm anun ağasıam/ Bâl u per ta'mîkda bî-pervâsıyam” şeklindedir. Bkz. Münîrî-yi Belgradî, Şerh-i Gazel-i Rusûhî, Milli Ktp, 06 Mil Yz A 2927/10, vr. 164b. [Münîrî risalesinden yapılacak iktibaslar için Çorum nüshası kullanılmış ve bu risaleyi temsilen sadece "Münîrî" ismi kullanılmıştır.]

38 Yûsuf Sinânüddîn, vr. 1b-2a. 
zarîf” olarak nitelenen Rusûhî̀nin bu tür şiirler söylemeyi bir âdet haline getirişi dikkat çekicidir. ${ }^{39}$ Sünbüliyye şeyhini asıl kızdıran durum ise tarîk-1 meşâyihin a'mâsı olan böyle bir zatın tasavvuf vadisinde âriflik davası gütmesidir. ${ }^{40}$

Yûsuf Sinânüddîn'in risalesinde Rusûhî̀nin yanı sıra devrin ileri gelenlerine dolaylı da olsa tenkit vardır. Risalenin telif tarihi kısmında da vurgulandığ1 üzere Rusûhî, gazelini yazar yazmaz bir cezayla karşılaşmamıştır. Zaten Yûsuf Sinânüddîn Efendi'yi reddiye yazmaya sevk eden amillerden biri de zendeka suçunun cezasız kalmasıdır. Sünbüliyye şeyhi, bir taraftan cezası geciken bu zatın şerrinin izalesini yüksek sesle dile getirirken, diğer taraftan "fitne" yi sindirmekle mükellef makamları işlerini yapmaya davet etmektedir:

“fî-hâze’z-zamân zümre-yi müselmânân ve cumhûr-1 ehl-i îmân olan ihvânumuz içinde 'ulemâ-yı dîndârân ve fukahâ-yı perhîzkârân edâmallahu eyyâmehum efendilerümüz vardur ki her biri âsmân-1 şerî‘atda bir necm-i hidâyet ve recm-i ehl-i gavâyet olup nûr-1 fetvâ ve fürûg-1 takvâlarından ehl-i ibâhat u evbâş mânend-i bûm u huffâş göz açmağa kudretleri ve yüze gelecek sûretleri yokdur”41

Zendeka ve ilhâdı cezasız bırakmayanların medhiyesi olarak okunabilecek bu satırlar Rusûhî türünden zındıklara cezasını kesmeyen makamların gizli bir tenkidi gibi de okunabilir. Zira risalenin sonlarına doğru, Rusûhî şahsında zendeka ve ilhâda gösterilen müsamaha Yûsuf Sinânüddîn'i rahatsız etmiş ve bunun sebebini sorgulamıştır. ${ }^{42}$ Ayrıca ibadetlerle gece gündüz zikredilen Mevla’nın bir yarı

39 Hakikat ve küfür arasında kalmış yahut küfür kokan sözlerin ardına gizlenmiş hikmetler için zarâfet kavramı kullanılmaktadır. Şathiye söylemek bir bakıma zarâfet kast etmektir. Âşık Çelebi ve Latîfîn nin Riyâzî maddesinde bu tür söyleyişlerin zarâfet olarak adlandırıldığını görmekteyiz: "tasavvuf resầiline dahı nazar iderdi ve zarâfet kasd idüp mahalline göre açık latîfeler iderdi." Âşık Çelebi, s. 1399; "ve zarâfet 'addidüp ilhâd u ibâhata müte'allik ba'zı kelimât ihtiyâr u irtikâb itdügi ecilden ekser-i nâs mezhebinde vüs'at ve ba'zilar ol sûret-i vüs'ati mahz-1 zarâfet 'add itdi”, Latîfî, Tezkiretüş-Şu'arâ ve Tabsıratün-Nuzamâ, nşr. Rıdvan Canım, (Ankara: Atatürk Kültür Merkezi Başkanlığı, 2000), s. 284.

40 "bir şâ‘ir-i zarîf ki hezliyyât u hicviyyât söylemek âdeti ve umûr-1 dîniyyede müsâmaha eylemek tabî‘atı iken vâdî-yi tasavvufda da'vâ-yı ta'arruf idüp ma ârif söylerüm diyü tekellüf ü tasallüf üzre beyt mescid-i iş̧kun imâmı olmışam/ deyr-i ‘şskun hem çelîpâpâsıyam/ ben ne dirsem Hakk anı eyler hemân/şöyle benzer ben anun agasıyam didükde...” Yûsuf Sinânüddîn, vr. 3 b.

41 Yûsuf Sinânüddîn, vr. 2b.

42 "bu makûle güftâra mutasaddî olan murdâr u bed-girdârı sengsâr ve yâhud ihrâk bi’n-nâr itdürmek iken müsâmaha vü müsâhelenün sebebi ma'lûmımuz olmadugından cigerimüz hûn ve derûnımuz gumûm u hümûm ile meşhûndur” Yûsuf Sinânüddîn, vr. $7 \mathrm{~b}$. 
molla tarafından tahfifine izin verilmesi ulemâ ve fukahâ için iki cihanda bir azap sebebibidir. ${ }^{43}$ Sünbüliyye şeyhine göre tövbe etmek yerine hâlâ sahibi tarafından inatla tevili imkândan hariç bu gazelin korunmaya çalışılması Rusûhînnin idamını gerektirmektedir. Çünkü bu makûle küfriyyât tevvilât-1 bâtıla ile bihasebi’ş-şer 'i'şşerîf [Rusûhî] 'afv olınursa kat'â bir kelime-yi küfr kalmaz ki çeke çevire ba îdden ba'îd te’vîle kâbil olmaya. ${ }^{44}$ Yani bir bakıma bu sözler de küfür kabul edilmezse, dünyada küfür denebilecek söz kalmayacak, hepsi tevil ile batıldan hakikate tebdil edilecektir. Rusûhî̉nin şerrinin izalesi için, "Eğer Allah bazı insanların şerrini bazular ile önlemeseydi dünyadaki nizam bozulurdu. Lakin Allah alemlere büyük lütuf ve inayet sabibidir." (Bakara/251) ayet-i kerimesinin hükmü bağlamında hareket eden Yûsuf Sinânüddîn, en azından kendi üzerine düşeni yapmak için harekete geçer ve Rusûhî̀nin gazelini cerh eden bir risale yazar. Yûsuf Sinânüddîn, risalesinde Rusûhînin oyunlarına gelerek imanlarını şeytana kaptırmamaları konusunda insanları uyarır, onlardan şairin müellefatını ciddiye almamalarını ister. ${ }^{45}$

\subsubsection{Rusûhî̉nin müdafaası ve Yûsuf Sinânüddîn'in tepkisi}

Rusûhînnin bahsi geçen bu isnatlar karşısında kendini nasıl müdafaa ettiğini de Tadlîldeki kayıtlardan anlıyoruz. Bu bağlamda Rusûhî̀nin kendini temize çıkarma adına bir fetva aldığı ve gazelini tevil eden bir mektup yazdığı dikkat çekiyor. Rusûhî̀ye ilk tepkiler gazelin ortaya çıkışının hemen ardından gelse de şairin tazir ya da hapis gibi herhangi bir ceza almadığ Sünbüliyye şeyhinin risalesinden anlaşılıyor. Buna göre Rusûhî yaygara koparan gazelini söyleyince ilk olarak, ismi risalede zikredilmeyen ehl-i sünnete mensup bir zümre tarafından kınanıp tövbeye davet ediliyor. Ancak Rusûhî tövbe etmek yerine kendini savunuyor ve asıl sıkıntının kelâmı her daim küfre yoran zâhir ulema ve meşâyihinda olduğunu belirtiyor. ${ }^{46} \mathrm{Bu}$ zümreleri ise altın ve incinin kıymetini bilmeyip onlara kıymetsiz

43 "pes revâ degüldür ki gice gündüz tấat u ibâdet idüp yâ Mevlâ diyü tazarru' u duâ itdügümüz Bârî Teâlâ Hazretine nev'an tahfîf ibhâm u îmâ iden kelâm-1 nâ-sezâya rizâ virüp dünyâ ve ukbâda rüsvâ olavuz." Yûsuf Sinânüddîn, vr. 3b. Yûsuf Sinânüddîn’in bu sözleri yazarken Kadı İyaz’’n Şifâ-yz Şerîf'inden büyük ölçüde etkilenmiş gözükmektedir: "Kendisine ibadet ettiğimiz Allah’a sövülür de biz onun intikamını almayız öyle mi? Öyle ise biz kötü kullarız, iyi kullardan değiliz." Bkz. Kadı İyaz, Şifa-i Şerif, terc. Naim Erdoğan-Hüseyin S. Erdoğan, (İstanbul: Çile Yayınları, 1977), s. 717.

44 Yûsuf Sinânüddîn, vr. 8a.

45 Yûsuf Sinânüddîn, vr. 2a; 4a.

46 Yûsuf Sinânüddîn, vr. 3b-4a. 


\section{RUSÛHÎ'NİN KUS DİLİYLE BİR GAZELİ VE \\ YÛSUF SINÂNNÜDDÎN İLE MÜNÎRÎ'NİN ŞAİRE REDDİYESI}

bir boncuk muamelesi yapmak, şer pazarında bu incileri eğri büğrü delerek yok fiyatına satmak ve Yûsuf'un güzellik güneşini balçıkla örtmekle suçluyor:

"bu devlet-hâh-1 sâlik-râh dahı nâşîden tahâşî idüp sadef-i dürer içre bir iki güher bahr-1 mescûrda mestûr itmiş idüm piloriler[i] har-mühre sanmışlar râygân buldukları içün alçak anlayup bâzâr-1 isầetde sarf-1 gıybeti bildükleri gibi almış satmışlar benüm yanumca niçe ekâbirün dürer-i nâ-süftelerini elmâs-1 'irzıla eğri büğri delmişler hüsn-i Yûsufı ma yûb [ile] güneşi balçığıla mahcûb itmişler”ł7

Tadlîldeki kayıtlardan Rusûhî̉nin kendini temize çıkarmak ve halk indinde itibar elde etmek için bir mektup yazarak bunu dönemin önde gelenlerine gönderdiğini Yûsuf Sinânüddîn'in: "Tèvîlât-ı bâtılasın kendü hattıyla yazup şarka ve garba Aceme ve 'Araba neşr idüp iştihâr ile iftihâr itdükde 'âmme-yi 'avâmm-ı nâs içinde fitne-yi 'azîmeye mü'eddî olup niçe müslimânun küfrine ve meşâyih-i 'zầma sû̀-i zannına bầis olduğın yakînen görüp ve bilüp..." şeklindeki sözlerinden anl1yoruz. ${ }^{48}$ Risalenin devamında ise Rusûhînnin bu mektubunu Sünbüliyye şeyhine de gönderdiği ortaya çıkıyor. ${ }^{49}$ Sünbüliyye şeyhinin riyakârlık olarak yorumladığı mektup, iki sûfinin arasındaki hesaplaşmanın arka planda bir kin, kırgınlık ya da düşmanlıktan kaynaklanıp kaynaklanmadığını tahmin konusunda bize ipucu veriyor. ${ }^{50}$ Zira iki sûfînin arasında açıktan bir küskünlük yahut düşmanlık olsa Rusûhî küs olduğu birine mektup göndermeyecektir. Buna istinaden şu an için iki sûfînin arasındaki bu hesaplaşmanın dargınlıktan kaynaklanma ihtimalini göz ardı etmek mantıklı gözüküyor. Bununla birlikte sekiz yapraklık bir risalede Yûsuf Sinânüddîn'in, reddiyeye konu olan Rusûhîyi ismiyle anmaktan özenle uzak durup şaire bir nevi hınzır muamelesi yapması ve Rusûhî için sarf edilen hakaret dolu kelâmlar Yûsuf Sinânüddîn'in bu zattan pek hoşlanmadığını ortaya koyuyor. Hatta Sinânüddîn Efendi hoşlanmamakla kalmıyor, Tadlîldeki:

47 Münîrî, vr. 2a.

48 Yûsuf Sinânüddîn, vr. 4 a.

49 "ol bed-sîretün sûret-i istiftâsıdur ki bu hakîr ü fakîre irsâl itmişdür tâ kim fazl u kemâlini göreler ve zamânede bu makûle ârif varımış diyü dâmânına yüz süreler” Yûsuf Sinânüddîn, vr. 4a.

50 Zındıklık ve mülhidlik suçlamalarında öne çıkan iddialardan biri zındıklık cürmünün bir kalkan olarak kullanıldığı ve olayın temel nedeninin taraflar arasındaki çekememezlik yahut düşmanlık olduğudur. Hemen birçok olayda benzeri iddialar dile getirilmiştir. Nadajlı Sarı Abdurrahman Efendi'nin vaziyeti buna bir örnektir. Zira Nadajlı'nın katli, halk arasında Esad Efendi'nin Nadajlı'yı çekememesi olarak yorumlanmıştır: "Bu bir acîb menkabedür Abdurrahmân Efendi'yi Es'ad Efendi ilmen iskât idemeyüp cebren şehid itdürüp bir acẩib kaziyyedür. "Bkz. Nadazlı Menkabesidür, İBB Atatürk Ktp., Osman Ergin, nr. 832, vr. 59b-60a. 
“'udûl u sikât [güvenilir kişilerin] şehâdetleri oldur ki şer'an mesâg [câiz] olmayan nesneleri irtikâb eyleye [...] ba'z-1 eş'ârında olan hezliyyât u hicviyyâtı ve ba'z-1 mahallerde kıssa-hân olup nakl itdügi hikâyâtı ol şehâdet eyleyen sikâta hüccet olmak kâbildür." satırlarına bakılacak olursa Rusûhî için bazı kişilerden istihbarat topluyor. $^{51}$

Rusûhî̀ye yöneltilen eleştiriler Rusûhî̉nin mektubu için söylenenlerle daha şiddetli bir şekle bürünüyor. Öyle ki bu mektup henüz çilesini tamamlamamış bir müridi hakikat ile hayal arasında çalkalayıp doğru yoldan saptırır, bir müddeînin eline geçse, tıpkı Rusûhînin yaptığı gibi, insanları kandırmak ve onlardan menfaat sağlamak için kullanılabilir:

“mübtedî olan sâlikler ol mektûba nazar itmek cầiz degüldür zîrâ nazar iden kimesneler şundan hâlî degül yâ tâlib-i sâdık ve yâhud müdde î-yi münâfik ola eger tâlib-i Hakk-ı hakîkat ise henüz tamâm-1 mücâhede itmemiş ve bakıyyeyi evsâf-1 zemîme-yi nefs-i emmâre var iken ol mektûb olan [o kağıtta yazılmış olan] merâtib-i âliyye ve tecelliyât-1 sâmiyyeyi görmek ve hıfz itmek ile kuvvet-i muhayyilesi mütekeyyife olup sebeb-i safâ-yı meşreb ile hayâlinde ba' $z-1$ ahvâl görüp hâl sanup ol makâma kendüyi vâsıl mulâhaza eyler dahı mücâhedesinde fütûr ve müşâhedesinde hezâr kusûr var iken magrûr olup derece-yi kemâlden münhat olur ve muhakkıkînün hayâlât-1 sûfiyye diyü zemm ü kadh itdükleri mekr-i 'azîme ve 'azâb-1 elîme mübtelâ olur ve eger müddề görse habs cibilleti ve sû'-i akîdeti mûcebince ol maârifi sirkat eyleyüp hutâm-1 dünyâya [dünya malına] vesîle ve sâde dil olup ehlullâha mẩil olan erbâb-1 devleti sayd itmegiçün mü’evvil-i muhîl gibi hîle ittihâz eyler." 52

Mübtedîleri dalâlete sürükleyebilecek kadar tehlikeli olan bu mektuba Münîrî risalesinin giriş kısmında rastlamaktayız. Her ne kadar risalede bu kısmın Rusûhî mektubu olduğu başlık vs. ile açıça belirtilmese de bu metnin Rusûhî̀ye ait söz konusu mektup olduğu kanaatini destekleyen üç ögeden bahsetmek mümkündür. İlki Münîrînnin, reddiyeye uğramış gazele dair kendi fikirlerine geçmeden önce sarf ettiği "... diyü nâzım 'arz-ı hâlün ihtitâmın böyle dimiş ve's-selâm” şeklindeki cümledir. ${ }^{53} \mathrm{Bu}$ ifadeden "nâzım" ile Rusûhînnin, "arz-1 hâl" ile de meşhur mektubun kast edildiği açıktır. Münîrî bu cümleden sonra risalesinde gazele dair

51 Yûsuf Sinânüddîn, vr. 6b.

52 Yûsuf Sinânüddîn, vr. 6ab.

53 Münîrî, vr. 4b. 
fikirlerini ortaya koymaya başlamaktadır. İkincisi Tadlı̂lde çürütülmeye çalışlan tevillerin hepsi, Münîrî risalesinin giriş kısmındaki bu mektupta dile getirilmiştir. Üçüncüsü ise mektubun "birinci tekil şahıs" eki kullanılarak yazılmış olmasıdır ki muhtemelen Münîrî, risalesinin girişine aldığı bu kısmı Rusûhî mektubundan kopya etmiştir. Rusûhînnin kendini savunarak gazelini ne şekilde tevil ettiğini göstermesi açısından bu mektup önemlidir. ${ }^{54}$

Rusûhînnin kendini kurtarma adına ciddi savunmalarından biri de kelâmının caiz olduğuna dair Ebussuûd Efendi’den aldığını iddia ettiği fetvadır. Sünbüliyye şeyhine göre merhum şeyhülislâmın böyle bir fetva vermesi mümkün değildir. Rusûhî bunu kendinden uydurmaktadır. ${ }^{55}$ Zira Ebussuûd Efendi (ö. 23 Ağustos 1574), gazelin ilk ortaya çıktığı vakitler hayatta olmasına rağmen, muhtemelen Yûsuf Sinânüddîn-Rusûhî kavgasının olduğu zamanlar vefat etmiştir. Dolayısıyla fetvanın sıhhatini şeyhülislâm kanalından sorgulamak mümkün gözükmemektedir. Rusûhînnin, Ebussuûd Efendi'den gazelin caizliğine dair aldığını iddia ettiği fetva Tadlîlde şöyledir:

"pes 'ulemâ-y1 'izâm hıdmetlerinde niçe müddet fünûn-1 'adîdeye müştagil olup fenleri mutâla'asında kemâl-i istikâmet ile müsellem ba'dehû tarîk-1 tasavvufda meşâyih-i kirâm hıdmetine vâsıl olup cemî́-i evzâ' u etvârı şer'-i şerîfe tamâm

54 Mektubun metni bu yazının "ek" kısmında sunulmuştur.

55 "hattâ şeyhu'l-islâm müftiyyü'l-enâm hazretlerine dahı istiftâ itdürüp te'vîlât u tevcîhâtumı arz eyledüm nesne lâzım gelmez diyü cevâb-1 şerîf virmişdür diyü hâş̧â ve kellâ iftirâ idüp...” Yûsuf Sinânüddîn, vr. 4a. "ol nâdân-1 adîmü'l-vicdânun kendü eliyile yüzi gibi karalayup bu hakîre gönderdügi sûret-i fetvâ-yı bî-fehvâsıdur ki şeyhu'l-islâma iftirâ idüp kizbe ictirâ itmişdür." Yûsuf Sinânüddîn, vr. 5a. Benzeri bir iddia Şeyhülislâm Zenbilli Ali Efendi için de dile getirilmiştir. İddiaya göre Zenbilli, sûfîlerin devran ile zikretmesine karşı çıkmamış, hatta bunu desteklemiştir. Bu hususta müsbet fetvalar vermiş ve bir de risale yazmıştır. Lakin Şeyhülislâm Çivizâde Mehmed Efendi'ye göre bu risale Zenbilli'ye ait değildir. Sûfîler tarafından kasıtlı olarak ona nisbet edilmektedir. Bkz. Öngören, s. 369-370. Krş. Mehmet Gel, “XVI. Yüzyıl “Lahn ve Tegannî” Tartışmalarına Dâir Bir Muammânın Çözümüne Doğru: "el-Kavlü’l-Vasît”in Müellifi İbn Bahâeddin mi?”, Tasavvuf: İlmî ve Akademik Araştırma Dergisi, sayı: 35, 2015, (dipnot. 19) s. 7. Ebussuûd Efendi hayattayken de birileri Musâhib Celâl'in için kendisinin adını kullanarak fetvâlar tertip etmiştir. İddiaya göre Musâhib Celâl, dinî akideleri ve ulemâyı hedef alan edep dışı bir manzume yazmış ve Ebussuûd Efendi bununla ilgili fetvâlar kaleme almıştır. Şeyhulislâmın bu fetvâları bir mektup ile Sultan II. Selim'e arz edilmiştir. Ebussuûd Efendi, bu mektup ve fetvâlarla ilgisinin olmadığını, bunu kimin sunduğunu veya sundurduğunu bilmediğini söylemiş ve durumdan şikayetçi olmuştur. Bkz. Abdülkadir Dağlar, Türkçe Mektupları Işıı̆ında Ebussuûd Efendi'nin Beşerî Münâsebetleri, Osmanlı Araştırmaları / The Journal of Ottoman Studies, XLI (2013) s. 305-306. 
mutâbık olan Zeyd-i mutasavvıfa mesâfe-yi ba'îdeden su'âl iden sâlike cevâb sadedinde beyt ben ne dirsem Hakk anı işler hemân / şöyle benzer ben anun ağastyam diyüp ve lâkin (آنى)'dan murâd ân-1 zamânî olup cüzv-i zamân olsa ben ne dirsem Hakk ânı eyler ya'nî hemân ol sâ'at eyler ya'nî fí li kavlüme mukârin eyler şöyle benzer ben ânun ya'nî ol vaktün ağası ya'nî abd-1 hâssıyam diyü sûfî-yi ibnü’l-vakt idügine işâret ve ef âli mukayyed bi'z-zamân olandan kinâyet olsa ve yâhud ihtiyâr-1 cüzvî mes'elesine tenbîh olınup ben ne dirsem ya'nî ben ihtiyâr-1 cüzvîmi neye sarf idersem 'âdetullâh anı halk idivirmekdür diyü ehl-i sünnet ve cemâ'at mezhebine işâret olsa ve yâhud 'ilm ma 'lûma tâbi' mes'elesi ki beyne'l'ulemâ şâyi'dür ma'lûmun 'âlimde eserini takrîr ve kuvvet-i te’sîrden ta'bîr idüp şeyhun ولمعلوم اثرفى العالم فماعلم الحق الاماكان فى عين المعلوم didügi üzre isti'dâd-1 ma'lûm 'âlimde idügine tenbîh olınup irâdet kadere kader kazâya kazâ 'ilme 'ilm ma'lûma tâbi' mes'elesi üzre ağa 'ibâretine cür'et olınup edât-1 teşbîh ile îrâd olınup nihâyet havâsdan olmak iddi'â itmiş olsa ve yâhud Hakk kelâmun sıfatı olup anun zamîri kầilün şeyhine râci' olup ben ne dirsem Hakk ya'nî kelâm-1 Hakk-1 şeyh anı işler şöyle benzer ben şeyhun ağası ya'nî 'abd-ı hâssıyam diyü şeyhinün kelâm-1 Hakka kemâl-i ittibâ'indan ta'bîr itmiş ola 'ale'l-husûs bu gazelün matla'1 Habîbullâh vasfında olup yanındaki beytler insân-1 kâmil vasfında

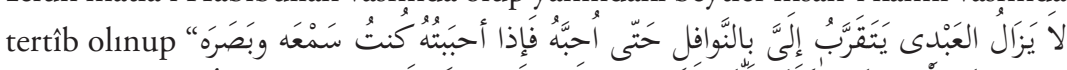

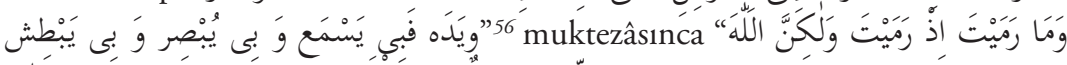

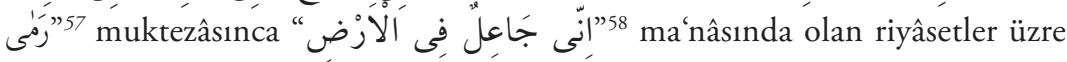
kurb-1 ma'hûd maksûd olup pâd-şâhun ağaları kulları olduğın takrîr itmiş olsa dâmen-i 'ismetini dest-i ta'addîden halâs u menâsa mecâl olur mı beyân buyurılup müsâb olına el-cevâb Allâhu a'lem olur" ${ }^{\prime}$

56 "Kulum bana nafile ibadetlerle devamlı yaklaşır, sonunda ben de onu severim. Bir kere kulumu sevince artık onun işiten kulağı, gören gözü ve tutan eli olurum.” [Bu rivayet farklı iki hadisten

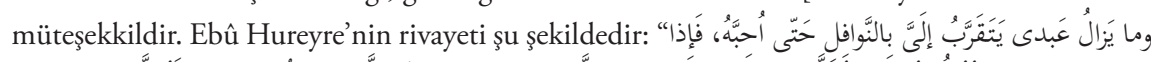

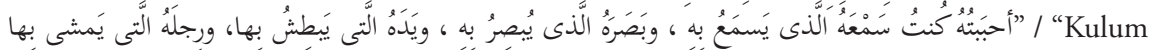
bána nafile ibadétler íle yáklaşır, sonuñda ónu severim. Bén kendisini sevince işiten kulağı, gören gözü, tutan eli ve yürüyen ayağı olurum.” Ebû Zekeriyyâ Muhyiddîn Yahyâ İbn Şeref en-Nevevî, Riyâzzü's-Sâlihîn Tercemesi, trc: Salih Uçan, (İstanbul: Arslan Yay., 1989), s. 363, hadis nu. 390. "فَبَى يَسْمَع وَ بَى يُبْصِر وَ بَى يَبْطش "Benimle işitir, benimle görür." el-Hakîm et-Tirmizî, Nevâdiru'lUsû́l 3/8́1.]

57 “(Ey Resûlüm) attığın vakit sen atmadın, lakin Allah attı.” Enfâl 17.

58 "Ben yeryüzünde [bir halife] yaratacağım.” Bakara 30.

59 Yûsuf Sinânüddîn, vr. 4b-5a. 
Fetvada Rusûhînin dolaylı yoldan kendini ve şiirini müdafaa edişi de göze çarpmaktadır. Fetvanın mes'ele kısmından şairin uzun yıllar ulema hizmetinde bulunup zahirî ilimleri tahsile çabaladığı ve sonrasında tasavvufa adım attığı anlaşılıyor. Sûfiyâne bir tarz benimseyen şair, heterodoks dervişlerden farkını ortaya koymak için "cemî'-i evzâ‘ u etvârı" nın şeriata tamamen uygun olduğunu vurguluyor. Bir nevi tarikatının şeriatsız olmadığını dile getiriyor. Şiirin müdafaasına gelince, Rusûhî bahsi geçen şiiri Ebussuûd Efendi'ye doğrudan yönelterek altıncı beyitteki ağa ibaresinin şer’an caiz olup olmadığını sormak yerine beyitle kasdettiklerini sıralıyor ve beyti şerh ü tevil ediyor. Bu tevile istinaden şeyhülislâmdan icazet alıyor. Rusûhînnin kendi ahvalini tamamen şeriata mutabık olarak tasvir etmesi Yûsuf Sinânüddîn'i öfkelendiriyor. Sinânüddîn Efendi, Tadlît in ilerleyen kısımlarında "müsteftî-yi mesfûr" terkibiyle andığı Rusûhî̀yi şeriata muhalif çevrelere karışmak, kibirlilik ve ilhada bulaşmakla suçluyor:

"müsteftî-yi mesfûr gurûr ile kendüyi medh idüp cemî'-i ąkvâl ü ef âli şer'-i şerîfe

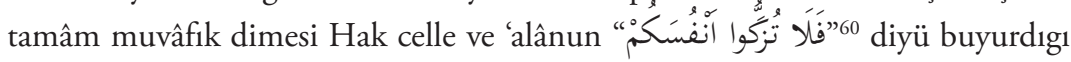
nehy-i İlâhîye muhâlif olduğından mâ‘adâ nefsinde hılâf vâkı'dur ekser-i evkâtı ehl-i hevâ ihtılâtıylla güzerân idüp ba'z-1 mecâlisde isti'mâl olınan menâhî vü melâhîden ictinâb [itmezdi]" ${ }^{\prime 1}$

\subsection{2. İlk hücum: Şeriata aykırılık}

Yûsuf Sinânüddîn ile Rusûhî hesaplaşmasının en temel noktası şeriata aykırılık olarak gözüküyor. Zâhir ehli ile bâtının, sûfî ile zâhidin ve tarikat ehli ile şeriatın mücadelesi şeklinde defalarca tezahür eden bu hesaplaşmalara ehl-i tarikın, tarikatı şeriattan üstün görmesi zemin hazırlıyor. Bazı sûfîler tarafından şeriatın özü yahut şeriat ötesinde bir safha olarak yorumlanan tarikat her durumda da şeriat üstü bir makam olarak görülüyor. Ancak bu fikrin tüm tarikat ehli için genel geçer olduğunu söylemek zordur. Tarikata karşı sünnet ve şeriatı öne çıaranlar da olmuştur ki Nakşbendîlik bu bağlamda öncüdür. Özellikle Nakşî silsileden Sirhindî, şeriatın tarikat için elzemliğini tafsilatlı ve sistematik olarak ele almıştır. Bu noktada tasavvufî amele eşlik eden tüm keşfî ve vecdî tecrübeler yalnızca sünnete bağ lılık ve şeriatı idrak ile anlam kazanmaktadır. Sirhindînnin

60 “Öyleyse kendinizi temize çıarmayın, övünüp durmayın.” Necm 32.

61 Yûsuf Sinânüddîn, vr. 6b. 
bu sözleri ile meyvenin kabuğu olarak tasavvur edilen şeriat ile meyvenin asıl kıymetli kısmı yani özü olarak tasavvur edilen tarikat yer değiştirmekte ve tarikat, şeriatın hizmetkârı olmaktadır. ${ }^{62}$

Rusûhînnin kendini temize çıkarma ya da [Sünbüliyye şeyhinin iddiasıyla] itibar kazanma adına yazdığı mektuba dair sözleri hatırlanacak olursa Yûsuf Sinânüddîn'in en baştan beri Rusûhî̀yi sünnete uymamakla itham ettiği rahatça görülür. Rusûhînin kendini savunmak için sarf ettiği evvelden beri meşâyihin sözlerinin ulemâ-yı rüsûm [zâhir uleması] katında küfür olarak addedildiği şeklindeki savunmasını çürütmek adına Tadlîlde tarikat için şeriatın önemini vurgulayan prestijli sûfilerin beyanlarını okuyoruz:

"tarîk-1 Hakkun ustâdı Hazret-i Şeyh Cüneyd-i Bağdâdî (ks.) buyurur bizüm mezhebümüz usûl-i kitâbet ve sünnet ile mukayyeddür kavlinde ve fílinde iktifâ-yı Resûl-i Hudâ itmeyen kimesneye bâb-1 âlî cenâb-1 hakîkat mesdûd olup kurb-1 Hazretden matrûd u mübáaddur bin yıl mücâhede dahı iderse müşâhededen dûr u mehcûrdur şeyh-1 ma'nevî vü sûrî Ebu'l-Huseyn-i Nûrî (ks.) buyurur bir kimesneyi görsen ki hâl da'vâ ider eger zevâhir-i şer'a muhâlif ise zinhâr karîb olma mübtedi'dür kâşif-i her râz Ebû Sa îd-i Harrâz buyurur her bâtın ki zâhire muhâlif ola bâtıldur bâtın degüldür mâni'-i vesvâs-1 hannâs Şeyh Ebu'l-'Abbâs buyurur lisân-1 bâtın oldur ki hükm-i zâhiri aslâ tagyîr itmeye müstağrak-1 eyâdî-yi hâdî Şeyh Ebu'l-Kâsım-1 Nasrâbâdî buyurur asl-1 tasavvuf kitâb ve sünnete mülâzemet ve âdâb-1 şerî‘ata müdâvemetdür vâris-i ilm-i nebî Şeyh Muhyiddînüll-Arabî (ks.) buyurur her hakîkat ki anı şerî́at reddeyleye zendakadur şerî́atı kâmil olmayanun tarîkatı dahı yokdur harem-i muhterem[de] Futûhât' t tahrîr iderken ba 'zı vâridâtı kırk kerre kitâb ve sünnete tatbîk itmeyince kayd-1 kitâbete getürmezidüm Şeyh Ebu'l-Kâsım-1 Kuşeyrî (ks.) buyurur ki cemî́-i meşâyıh ittifâk itmişlerdür ki ta'zîm-i zevâhir-i şer` vâcibdür tarîk-1 riyâzete sülûk iden tâlib-i Hakka lâzımdur

62 Hamid Algar, Nakşibendîlik, (İstanbul: İnsan Yay., 2012), s. 37-38. Sirhindînin, müridi Hacı Lahorî̀ye yazdığı mektupta şeriat-tarikat dengesi şöyle ifade edilmiştir: "Şeriat üç kısımdan mürekkeptir: ilim, amel ve ihlâs. Bu üçü mevcut olup gerçekleştirilmedikçe şeriatın ifa edildiği söylenemez. Şeriat ifa edildiğinde Allah'ın (c.c) rizası gerçekleşir iki dünya ve ahiretteki saadetin tüm biçimlerinden daha üstündür... Şeriat hem dünya, hem de ahiretteki tüm saadetlerin teminatıdır ve insan için şeriattan gayrı ihtiyaç duyacağı herhangi bir nesne bulunmamaktadır... Tasavvuf ehlini toplumun diğer kısmından ayıran tarikat, şeriatın hizmetkârıdır ve onun üçüncü unsuru olan ihlâsın kemâle erdirilmesi vazifesini görür. Tarikata ulaşmanın amacı şeriata ilave bir şeyler oluşturmak değil, sadece şeriatın kemâlidir... Manevî halleri ve cezbe anlarını bu yolun amaçları arasında hayal eden ve keşfi tecrübenin bu yolun amaçlarından olduğunu varsayan o basireti kıt kimseler, kaçınılmaz olarak kuruntu ve hayalin hapsine kapılacaklar ve şeriatın mükemmelliklerinden mahrum kalacaklardır." Bkz. Algar, s. 38. 


\section{RUSÛHÎ'NİN KUS DİLİYLE BİR GAZELİ VE \\ YÛSUF SİNÂNÜDDÎN İLE MÜNÎRÎ'NİN ŞAIIRE REDDİYESI}

ki sünnete mutâba'at ve âdâba mülâzemet eyleye şol kimesne ki kavlinde ve fílinde vera' u takvâ bârî zâhir-i fetvâ ile mukayyed olmaya dâll ü mudıldür tarîk-1 Hakka muhıldür iki cihânda meftûn ve 'azâb-1 elîme makrûndur'c3

Bu tarz beyanların tek bir şeyin altını çizdiği ortadadır. Tarikat, şeriatsız olmaz. Şeriata muhalefet tarikata muhalefet demektir. Sünnet ve şeriata uymayan bir kişi kendisinde meydana gelen batılı hakikat zannedip batını arzularken batıla saplanır. ${ }^{64}$ Sinânüddîn Efendi, ünlü sûfîlerin sözlerini tafsilatıyla verme sebebini meşâyih-i kibâr ile ehl-i dalâlin hallerini ortaya koymak olarak belirtir. Çünkü ona göre sapkın sûfiler gerek hakiki sûfilere gerekse ulemaya iftira etmekten çekinmez, ayrıca hakiki sûfilerin hiçbirinden şeran küfür sadır olmaz. ${ }^{65}$

Rusûhî için diğer darbe, şairin marifet kasdıyla söylemiş olduğu iddia edilen sözleridir. Genel anlamda, şairin müellefâtı içerisinde yer alan bu tarz sözlerin amacı Sinânüddîn'e göre Rusûhînnin batıl mezhebini takviye çabasından başka bir şey değildir. İlhâd ile suçlananlar için bu yöntemin oldukça kullanışlı olduğu söylenebilir. Bunun bir örneğini Latîfî tezkiresinden okumak mümkündür. Tezkireye göre Temennâyî ve Kâşifî adlı iki sûfî şair batıl mezheplerini hak göstermek için eğri sözlerini çeşitli din ulularının sözleriyle takviyeye çalışmışırır. ${ }^{66}$ Yûsuf Sinânüddîn'in vurgularına bakılacak olursa Rusûhî de bu kullanışlı yöntemi benimsemiş gözüküyor: "Takviyet-i mezheb-i bâtılı içün nakl itdügi kelâm ki قن kavlidür kimün kelâmı idügi ma lûmumuz olmayup ve ilèl-ân kütüb-i meşâyih-i mu'teberede görilmiş ve işidilmiş nesne degüldür." ${ }^{67}$ Yûsuf Sinânüddîn'e göre Rusûhînnin ünlü sûfilerden iktibas ettiği, mevzuyu ulemâ-meşâyih çekişmesiymiş gibi gösteren bu sözü sahih değildir, sahihse bile Rusûhî bu kelâmın manasından gafildir. Zira Rusûhî tarafından: "Biz bir bölük tâyifeyüz ki mü’ellefât u musannefâtumuz şer'an küfr 'addolınan akvâl ile meşhûne ve ilhâd u zendekaya delâlet ider elfâza makrûnedür nazar iden kimesne mülhid ü zındîk olmak lâzım gelür imdi bizüm kitâblarumuza nazar itmek harâmdur." şeklinde izah edilen bu

63 Yûsuf Sinânüddîn, vr. 5b.

64 Yûsuf Sinânüddîn Efendi batılı batın zannedenlere örnek olarak ise Şeyh Bedreddîn ile Hurûfileri gösteriyor. Buna göre Hurûfîler "hayâl" i "hâl" zannederek manayı bir köşeye atmışlar ve şekle takılarak özü ihmal etmişler. bkz. Yûsuf Sinânüddîn, vr. 6a.

65 Yûsuf Sinânüddîn, vr. 6a. [Sinâneddin Efendi bunları söylerken şathiyeleri ile ün salmış Bâyezîd-i Bistâmî gibi birçok sûfîyi hesaba katmamış gözüküyor.]

66 Latîfî, s. 201.

67 Yûsuf Sinânüddîn, vr. 6a. 
iktibas Sinânüddîn tarafından tenkit edilmekte ve Rusûhî meşâyih kelâmının zâhirinden dahi habersiz tasvir edilmektedir. ${ }^{68}$

\subsection{3. İkinci hücum: gazelin cerhi}

Üzerinde ciddi tartışmalar olan bu gazel, matla'ın "Habîbullâh medhinde" olduğu, dikkat çekici beyitlerden olan "Mescid-i 'işkun imâmı olmışam / Ehl-i deyrün hem çelîpâpâsıyam" beytinin "insân-1 kâmil" vasfinda söylendiği ve gazelin en çok tepki çeken beyti olan "Her ne dirsem Hakk anı eyler hemân / Şäyle benzer ben anun ăgasiyam" beytindeki ăgadan kastın ise "kul yahut hizmetkâr" olduğu şeklinde Rusûhî tarafından şerh ü tevil edilmiştir. ${ }^{69}$

Yûsuf Sinânüddîn Efendi, gazelin reddiyesine ilk olarak Rusûhînnin "insân-1 kâmil” vasfında olduğunu iddia ettiği beyitten başlamıştır. Sinânüddîn'e göre bu beyt insân-1 kâmil'in tavsifini yapmaktan çok uzaktır. Rusûhî bu iddiayı kendi küfrüne kılıf için ortaya atmıştır. Rusûhî̀nin insân-1 kâmillik iddiasına karşın, Sünbüliyye şeyhi şairi papazlık [çelîpâpâsıyam] ile itham etmektedir:

"sûrete getürmekden havf idüp insân-1 kâmil vasfinda diyü bir kizb dahı itmişdür insân-1 kâmil vasfinda didügi beyti budur beyt 'Mescid-i ‘ş̧kun imâmı olmışam / Deyr-i 'i̧̧kun hem çelîpâpâssyam gerçi bâtılun murâdı çelîpâ ayağıyam' dimekdür ve lâkin ol ma'nâyı ifâde gerçekden murâdı olsa deyr-i 'ışkun dimeyüp deyr-i 'ışkda dimek gerek idi deyr-i 'işun diyicek kilîsâ pâpâsıyam dimegi ziyâdece kasd idüp ibhâm degül bitarîki'l-mantûk murâd idinmişdür zîrâ mescidün imâmı mukâbelesinde îrâd idicek pâpâsluk mukarrer murâdı olur ve yâhud çelîpâ-pâs vasf-1 terkîbî olup hâfız-1 çelîpâ dimek ola yine pâpâsluk mukarrer[dür] lâcerem sevk-i kahr-1 İlâhîyi gör ki mukaddemâ bu beyti diyüp kendü küfrine mu'terif ol[ur] ${ }^{370}$

68 “hâşâ ve kellâ mü’evvil-i câhil kelimât-ı meşâyıhun zâhirinden dahı gâfil olup hâtib-i leyl gibi 'ale'l-'amyâ şundan bundan derüp çatdugı zehârifi ma ârif zan itdügine ve tarîk-1 zîg u dalâla gitdügine bu akl-1 'akîmi ve fehm-i sakîmi delîl-i kavîdür belki ol kelâmun ma'nâ-yı sahîhi dimekdür ki biz bir bölük kavmüz ki hâlet-i istigrâkumuzda vâkı' olan ezvâk ve mevâcîd ve levâmi'-i esrâr-1 tevhîd gâhî bi'z-zarûre nefse-yi masdûr gibi butûndan zuhûr ve kümûndan bürûz u sudûr itmek takâzâ idüp mastûr olur." Yûsuf Sinânüddîn, vr. 6a.

69 Rusûhînnin kendi gazelini şerhi için ek kısmındaki mektuba bakılabilir.

70 Yûsuf Sinânüddîn, vr. 6b. [Sinaneddîn'e göre, Rusûhînin şath olarak tesmiye edilen bu tarz şiirler söylemesinde pratik bir fayda da söz konusudur. Rusûhî şöhretini artırıp "erbâb-1 devlete" 
Pâ "ayak" ve çelîpâ "haç, put, büklümlü çizgi, kâkül ve İncil rahlesi" anlamlarına geldiğinden "çelîpâ-pâ"sı ile çelîpânın ayağı kast ediliyor. ${ }^{71}$ Ancak Yûsuf Sinânüddîn bu ibarenin çelîpâ ayağı olarak anlaşılabilmesi için ikinci mısranın "deyr-i 'ş̧kda" şeklinde olması gerektiğini iddia ediyor. Aksi takdirde ibare çelîpâpâsıyam biçimine dönüşecektir. Yazmalarda cîm ve çîm harflerinin birbirlerinin yerine kullanımları göz önüne alınacak olursa "çelî" "celî" olarak da yorumlanacak ve beyit, "Aşk mescidinin imamı olmuşum, aşk kilisesinin celî/seçkin bir papazıyım.” biçiminde anlaşılacaktır. Ayrıca Sinânüddîn Efendi firarî şairi iki mısranın mütekabiliyetinden hareketle de kilise papazı yapıyor: Mescid-i aşkın imamı olunuyorsa deyr-i aşkın da papazı olunur. Sinânüddîn'in diğer iddiası ise bu ibarenin "çelîpâ-pâs" şeklinde vasf-1 terkîbî kabul edilip "hâfiz-1 çelîpâ" yani haç muhafazacısı anlamında kullanılabileceğidir ki neticede Rusûhî için tüm yollar “insân-1 kâmil”e değil kilise papazlığına çıkmaktadır. ${ }^{72}$

Gazelin en çok patırtı koparan beytinin altıncı beyit olduğu âşikâr. Buradaki "ağa" kelimesi beytin tevilini epeyce zorlaştırmış gözüküyor. Rusûhî bu beytin tevili için farklı iddialarda bulunuyor ki ilki anı (آن) demekten kastın "ân-1 zamânî” olduğu iddiası. Şu durumda beyitteki “o" zamiri vakit anlamıyla "ân”a tevil edilmiş oluyor. Yûsuf Sinânüddîn şairin bu beyte dair dile getirdiği teviller için şunları söylüyor:

yaklaşma ve bu sayede ehlullâha mẩil olan "erbâb-1 devleti sayd etme" hevesindedir.] Yûsuf Sinânüddîn, vr. $6 \mathrm{~b}$.

71 Mehmet Kanar, Arap Harfli Alfabetik Osmanlı Türkçesi Sözlüğü, (İstanbul: Say Yay., 2012), s. 405.

72 Aslında divan şiiri ve sûfî terminolojisinde bu türden benzetmeler epeyce kullanılmış ve çok da tepki uyandırmamıştır. Genelde sembolik bir anlam ifade eden deyr, büt, harâbât, mey, meyhane, pîr-i mugân gibi birçok kelimenin kasıtlarının farklı olduğu sürekli dile getirilmiştir. Söz gelimi beyitte geçen "deyr-i 'ş̧k" için söylenenler şöyledir: “...keyfiyet-i 'ş̧k ile şûriş-i câm-ı cezbe ile âş̧ıları meczûb itmegin her biri mestâne elkâblar ve ferzâne esmâlar ıtlâk idüp ba'zı pîr-i mugân ve ba'zılar pîr-i hammâr ve ba'zılar pîr-i harâbât ve ba'zı deyr-i 'işk ve ba'zılar humhâne-yi vahdet dirler. Her hâletde bir ismile müsemmâ iderler ehlullâh yanında ma'zûr u makbûl.” İsmail E. Erünsal, XV-XVI. Asir Bayrâmî-Melâmîliğinin Kaynaklarından Abdurrahman El-Askerî̀nin Mir'âtüll-Işkı, (Ankara: Türk Tarih Kurumu Yay., 2003), s. 164. Ayrıca "deyr" için Ethem Cebecioğlu şunları kaydetmektedir: "Arapça manastır demektir. Tasavvufî olarak şu anlamı ifade eder: İnsanlık âlemi. Düveyre: Zâviye. Deyr-i muğan: Mecûsî rahiplerinin ibadethanesi, muğların mabedi. Bu ifade, tasavvufî olarak arif ve evliya toplantısı anlamındadır." Cebecioğlu, s. 167. Yûsuf Sinânüddîn’in bunlardan haberi olmadığını düşünmek imkânsız. Anlaşılıyor ki terimlerin sembolik anlamlarını öne sürmek yerine zâhirî anlamlarını konuşmak Sinânüddîn'in daha çok hesabına geliyor ve Rusûhî ile bu bağlamda bir hesaplaşma zemini tesis ediyor. 
"zîrâ bu makûle kelâm-ı küfr-hıtâm ehl-i İslâmdan sâdır olmak muhâldür hâneyi îmânını esâsından vîrân eyleyen beytün tevcîhinde birkaç vech ki yazılmışdur cümlesi fâsiddür evvelâ anı dimekden murâdum ân-1 zamânîdür dimek ne makûle vâhî sözdür beyt nâ-mevzûn olmak kabâhati tursun iki mısâ‘ biri birine merbût olmaz zâhir budur ki hakdan murâdı Allâh tebâreke ve teâlâ celle ve alâdur ben ne dirsem Allâh Te âlâ aslâ sözümi reddeylemez ve murâdı tẻhîre komaz diyü kâzib da'vâ itdükden sonra şöyle benzer ben ol vaktün ăgası ya'nî ábd-ı hâssıyam dimek ne asl avurt savurtdur." ${ }^{\text {?3 }}$

“O” zamirini vakit anlamıyla “ân”a tevil etmek, Sinânüddîn Efendi’nin de belirttiği üzere, teknik anlamda Rusûhînnin aleyhine, terminolojik anlamda ise Rusûhî’nin lehine gözükmektedir. Teknik olarak Rusûhî̀yi zorda bırakan durum her iki mısrada da geçen "ân” kelimesinin gazelin veznini ikinci tefilelerde aksatmasıdır ki Yûsuf Sinânüddîn bu durumu "beyt nâ-mevzûn olmak kabâhati şöyle dursun" sözleriyle ortaya koymaktadır. ${ }^{74}$ Acaba o zamirini vakit anlamıla "ân"a tevil etmekten Rusûhî nasıl bir kâr sağlamaktadır? Bu soruya cevap için sûfîlerin vakit (ân) ile neyi kast ettiklerine bakmak yerinde olacaktır.

Sühreverdî̀den "vakit” kavramına dair şunları okumaktayız: Vakitten maksat kula hakim olan şeydir. Vakitle kulun irâde ve gayreti dışında üzerine hücum eden hâller kast edilir. Bunlar onda istediği gibi tasarruf eder ve kişi hâllerin hükmü altında kalır. Bu yüzden 'Filan kimse vaktin hükmü altındadır.' denilir. Bu sözün manası kulun kendi iradesinden alınıp Hak ile beraber olması demektir. $^{75}$ Bunun yanında sûfîye ânın çocuğu (ibnü’l-vakt), yani kendini tamamen âna veren kişi denmiştir. Buna göre ibnüll-vakt olan sûfî manevî hâlleri tecrübe eder, irade ve hürriyetini işe katmadan İlâhî tecellîye teslim olur. ${ }^{76}$ Rusûhî vezin kusuru pahasına "ân”a sarılarak “ibnü’l-vakt”e atıfta bulunmakta ve bu sayede zındıklık töhmetinden kurtulmaya çalışmaktadır. Ancak Yûsuf Sinânüddîn, bu beyitte ibnüll-vakte işarette bulunulduğu iddiasına itirazda bulunmak suretiyle Rusûhînin, tabir caizse, ibnü'l-vakt olmanın nimetlerinden faydalanmasını engellemek istemektedir:

73 Yûsuf Sinânüddîn, vr. 6b.

74 Ben ne dirsem/Hakk ânı iş/ler hemân // Şöyle benzer/ben ânun a/ğasıyam [Bu tasarruf sonuncunda beytin vezni olan "Fấilâtün Fấilâtün Fấilün"e göre her iki mısrasında ikinci tefilesinde zihaf gerekecektir.]

75 Sühreverdî, Tasavvufun Esasları: Avârifü̉l-Meârif Tercemesi, nşr. H. Kâmil Yılmaz-İrfan Gündüz, (İstanbul: Vefa Yay., 1990), s.657-658; krş. Kadir Özköse, “İbnü’l-Vakt ya da Ebu’l-Vakt Olabilmek", Sûfî Perspektif, 64, 2006, ss. 22-25.

76 Kadir Özköse, s. 23. 


\section{RUSÛHÎ'NİN KUS DİLİYLE BİR GAZELİ VE \\ YÛSUF SİNÂNÜDDÎN İLE MÜNÎRÎ'NİN ŞAIIRE REDDİYESI}

“sûfî-yi ibnü’l-vakt dimek vakt oğlı dimek degüldür ki oğul dimek cầiz olıcak kul dimek ve dahı ağa dimek dahı câiz ola ebu's-su'ûd ve ebu'l-fazl dimegi su'îd babası ve fazl babası dimek zannider gibi bu idrâk-i fâsid ve fehm-i kâsid ile 'ulemâ-yı ' 'zâm yanlarında istikâmet-i mutâla'a da'vâ itdügi garîb temâşâdur.”77

Beytin ilk mısrasını ibnüll-vakt ile açıklayan Rusûhî ikinciyi, "Pâdşâhbun ăgaları kulları oldugın takrîr itmiş olsa...” sözleriyle açıklamaya çalışıyor. Böylece beyit, Hakk'ın ağasıyım şeklindeki bir anlamdan ânun ağası yani ânın(vaktin) kuluyum yahut onun kuluyum şeklindeki bir anlama dönmüş oluyor. Şairin iddialarını inandırıcı bulmayan Yûsuf Sinânüddîn, Rusûhî̀nin ilk mısra için söylediği "[burada] ihtiyâr-ı cüzvî mes'elesine tenbîh olınup ben ne dirsem ya'nî ben ihtiyâr-ı cüzvîmi neye sarf idersem 'âdetullâh anı halk idivirmekdür diyü ehl-i sünnet ve cemâ'at mezhebine işâret olsa" tarzındaki sözlerini kabul edilebilir bulmasına rağmen, ikinci mısradaki ağa kelimesiyle Rusûhî̀yi vurmaya çalışıyor: "Sâniyen ihtiyâr-ı cüzvî mes'elesine tenbîh olmak mısrấ-ı evvelden çeke çevire çıksa kâbildür fe-ammâ mısrâ'-ı sânîde olan ăgasın kanda saklar ola asl hod gavgâ ăgadadur" dedikten sonra Rusûhînin ă̆ayı "kul"a tevilini mantıksız bulur. Zira padişahın, kulların her isteğini yerine getirip kullarının sözünden çıkmaması çok mantıklı gözükmemektedir:

"pâd-şâhun ağaları néam kullarıdur ve lâkin kullar her ne dirse pâd-şâhlar anı işler dimek 'abes sözdür fulân kimesne bana aslâ ve katầ muhâlefet idüp kelâmumı reddeylemez her ne dirsem elbette işler gûyâ ki ben anun ağasıyam dimegün ma'nâsın ekyes-i nâsdan fehm ider kimesne bulınmayup bi'z-zarûrî tehfîm-i halk içün şerh ü beyâna muhtâc oldum dimek ister hayfâ ve dirîgâ ne günlere kalduk"78

Tadlîldeki bu iktibastan, Rusûhînnin en az gazeli kadar tenkit edilen mektubunu neden yazdığını bizzat kendisinden öğrenmiş oluyoruz. Sünbüliyye şeyhine göre sahibine itibar kazandırma dışında bir amacı olmayan bu mektup, Rusûhîye göre bir zarurete istinaden kaleme alınmıştır ki o zaruret, muammâ-vârî bir üslûba sahip bu gazelin şifrelerinin, yine kendisi tarafından çözülmesi ihtiyacıdır. Yani Rusûhî gazeli şerhe mecbur kaldığı için bir mektup kaleme almıştır. Rusûhî tercih ettiği, kavranması pek de kolay olmayan üst perdeden bu üslûbu [ta'miye ve elgâz1], kullanışına gerekçe olarak "tarîkını ağyârdan setr etme"yi göstermektedir.

77 Yûsuf Sinânüddîn, vr. 6b.

78 Yûsuf Sinânüddîn, vr. 7b. 
Ancak Sünbüliye şeyhi, Rusûhî̉nin izahını bir bahane olarak görmüş ve şairin asıl niyetinin [ta'miye üslûbuyla] küfrünü örtmek olduğunda israr etmiştir. ${ }^{79}$

Rusûhî̀nin "ağa”yı tevil için öne sürdüğü iddialardan birisi de genelde kaderkaza konularında bahis mevzusu olan "ilmin malûma tâbi olduğu" meselesidir. Tadlîlde İbnüll-Arabîyye nisbet edilerek dile getirilen " ولمعلوم اثرفي العالم فماعلم الحقان الاماكان في عين المعلوم "sözü Rusûhî tarafından "istídâd-ı ma'lum âlimde idügine tenbîh”olarak ele alınmış ve irâdenin kadere, kaderin kazâya, kazânın ilme, ilmin ise ma'lûma tâbi' olması hasebiyle ağa ibâresine teşbih ile başvurulduğu belirtilmiştir. ${ }^{80}$ Yûsuf Sinânüddîn, gerek İbn Arabî̀nin bu sözünü, gerekse "ilmin malûma tâbi olduğu” meselesini kavrayamadığ için Rusûhîye karşı çıkmıştır. Üstelik Rusûhî sadece mevzuyu yanlış anlamakla kalmamış, "kütüb-i kelâmiyyeyi İslâmiyyede" tafsilatlı olarak işlenen bu konuyu "rumûz-1 hafiyye-yi sûfiyye" olarak sırf sûfilere mal etmiştir:

"ma'lûmun âlimde eseri takrîr [olınmış] ve [ol eserün] kuvvet-i te’sîr[in]den ta'bîr [kılınmış] didügi küfrdür zîrâ hazret-i 'âlim (...) mü’essirdür müte’essir olmak infiâldür zât-1 Bârî celle zikruhûda mümteni' ü muhâldür fe-keyfe ki te’sîrde kuvvet dahı ola Hazret-i Şeyh-i Ekberün (ks.) Fütûhât-ı Mekkiyye’de didügi ol zâlim[ün] fehm itdügi mánâ degüldür eserden murâd ilm-i icmâlîdür (...) ba'dehû fâ-yı fasîha ile murâd-1 sahîhi tasrîh idüp فماعلم الحق الاماكان فى عين dimesiyle ma'nâ-yı maksûdı keşf ü îzâh itmişdür isti'dâd-ı ma'lûm âlimde hâkim dimek dahı edebden hâric sözdür”"sı

79 "sâbıkan hod tarîkını ağyârdan setr itmek içün ta'miye ve elgâz diyü lâf u güzâf ideridi [...] her mübtedîye evzah ibâret ile ta'lîm ü tefhîm itmek vâcib iken ta'miye ve elgâz diyü elfâz-1 küfri îrâd itmek ne cehâlet ve dalâletdür" bkz. Yûsuf Sinânüddîn, vr. 6b-7a.

80 Yûsuf Sinânüddîn, vr. 4b-5a. Fusûsu'l-Hikem'in Şit fassında, Rusûhînnin söylediklerini aksettirir tarzda şunlar aktarılmaktadır: Hakk'ın sıfat ve esmâsına olan ilmi, zâtına olan ilmidir. Böyle olunca ilim kadîm, ma'lum da kadîm olur ve ilim ma'lûma tâbi'dir denilince evvelâ ma'lûm hâdis olur, ba'dehû ilim de ona lâhık olur, ma'nâsı anlaşılmamalıdır. Ma'lûmun ilme takaddümi, takaddüm-i zamânî değil, takaddüm-i aklîdir. Meselâ: "Falan kimse bildi." denilse akıl: "Neyi bildi?” diye sorar. Demek ki akıl, ma 'lûmu ilme takdîm ediyor. İște aklen, evvelâ ma lûm ve sonra da ona lâhık olacak "ilim" mevcûd olmak lazım geldiği için, ilim ma lûma tâbi" olmuş olur ve ma 'lûm olmayan şey murâd olunamayacağından irâde de ilme tâbi' olur ve irâde olunmayan şey hakkında sarf-1 kudrete mahal olmayacağından kudret dahi irâdeye tâbi'dir. Ahmed Avni Konuk, Fusûsu'l-Hikem Tercüme ve Şerhi, c. I, nşr. M. Tahralı-S. Eraydın, (İstanbul: Marmara Ü. İlahiyat Fak. Vakfi Yay., 2005), s. 197-198.

81 Yûsuf Sinânüddîn, vr. 7a. 
Bu sözlerin ardından Yûsuf Sinânüddîn "ilim malûma tâbidir"i kaza ve kader ölçeğinde ele alıyor. Söz gelimi bir insanın ölümüne hükmetmek (hükm-i icmâlî) kazadır. Kader ise bu hükmün sebep ve zaman gibi ögelerle tafsil edilmesidir: "Zeydin falan zamanda, falan marazdan fevt olmasına hüküm gibi." Kaza ve kader mevzularını açıktan tartışmayı "memnû" olarak niteleyen Sinânüddîn Efendi "sırr-1 kader" in bazı nebilerden dahi gizlendiğini dile getirmektedir. Üzeyr Peygamber'in bu sırrın keşfinde ısrarı üzerine kendisine Allah Teala'dan: "Yâ Üzeyr eğer bu hâtırdan ferâgat eylemezsen nâmunı dîvân-ı nübüvvetden ihrâc iderin." şeklinde bir uyarı gelmiştir. ${ }^{82}$

Altıncı beyit için Rusûhînnin öne sürdüğü son iddia ise beytin "mürid” tarafından "mürşid"e bir medhiye olduğu şeklindedir. Tadlîldeki: "Rabi'an 'hakk' kelâm-1 mahzûfun sıfatı olup anun zamîri kẩilün [gazeli söyleyen müridin] şeyhine ầid olmak murâd olıcak bu kavl-i bâtılun kẩili mürîd-i câhil olup şeyhini medh itdügi olur." ifadelerine bakılacak olursa bu beyit, bir mürîdin dilinden söylenmekte ve "hakk" sıfat olarak beyitten düşmüş bir kelimeyi (şeyhi/mürşidi) nitelemektedir. İkinci mısradaki "anun” ise düşen bu kelimenin zamiri olarak kullanılmaktadır. Bu durumda beytin anlamı şöyle olacaktır: Ben (yani mürid), ne dersem hakk (olan şeyhim/ hakikat ehli mürşidim) anı (dileğimi/duamı) eyler hemân / Benzer ki ben anun (yani hakikat ehli mürşidimin) ağasıyam (onun has bir bendesiyim).

Gazelin matlaı ile ilgili Rusûhînnin iddiası bu beytin "Habîbullâh vasfinda” olduğu şeklinde idi. Yûsuf Sinânüddîn bunun asılsız olduğunu vurguluyor. Tadlîlin bu kısmında gazelin dillerde dolaşan iki farklı matlaı olduğundan da haberdar oluyoruz. İlk matla: "Gizlü gencün lü’lü’-i lâlâsıyam / Şöhre-yi şehrem cihân kâlâsıyam” şeklinde. İkinci matla ise: "Küntü kenzün remzinün mevlâsıyam / Zât-1 bahtun 'alleme’l-esmâsıyam” biçiminde. Sünbüliyye şeyhi matlaın eleştirisini yaparken ikinciyi kullanıyor. Burada gözüne kestirdiği ise "mevlâ" ibaresi. Kavram olarak "mevlâ" seyyid anlamına geldiğinden altıncı beyitteki "ağa” ya yakın anlamda kullanılıyor. Gerçi Yûsuf Sinânüddîn, mevlânın "abd” manasına geldiğini de söylüyor, ama yine de bu tevriyeyi çirkin buluyor. Yûsuf Sinânüddîn’in en çarpıcı tespiti, matlaı Habîbullâh vasfinda söylediğini iddia eden bu şairin, mektubunda Hz. Peygamber' in ismi geçtiğinde salât u selâmı yazmaması. Sünbüliyye şeyhine göre bu tarz ipuçları Rusûhînnin tahkik değil taklid ehli olduğunun açı bir göstergesi. ${ }^{83}$

82 Yûsuf Sinânüddîn, vr. 7a.

83 Yûsuf Sinânüddîn, vr. $7 \mathrm{~b}$. 


\subsection{Olayın dolaylı muhatabı: Münîrî-yi Belgradî (ö. ?)}

Münîrî-yi Belgradîyi dolaylı muhatap sayma sebebimiz olayın doğrudan Yûsuf Sinânüddîn ile Rusûhî arasında vuku bulmuş olmasıdır. Bununla birlikte Münîrî risalesinden "Rusûhî” nin mektubu" ve "şairin III. Murâd'ın tahta çıktı̆̆ ilk yıllarda sürgün edildiği” gibi bilgilere ulaşmak da mümkündür.

Risale, Milli Kütüphane nüshasında "Risâle-yi Münîrî Efendi el-merhûm rahmetullâhi 'aleyhi rahmeten vâsi'aten" ve Çorum nüshasında ise "Yầ Fettâh" ibaresiyle başlıyor. Milli Kütüphane nüshasında ketebe kaydı olmadığından risalenin telif tarihine dair bilgi yok. Çorum nüshasındaki tarih kaydına [f̂́-seneti selâse ve erba'în ve elf] göre ise Münîrî risalesinin h.1043 (1634) yılında istinsah edildiği anlaşılmaktadır. Aynı nüshada Münîrî için kullanılan el-merhûm ifadesi bu nüsha istinsâh edilirken Münîr̂̀-yi Belgradî nin hayatta olmadığını gösteriyor. ${ }^{84}$ Eldeki iki nüshadan risalenin telif tarihini tesbit etmek tam olarak mümkün değildir. Ancak risalenin 8b varağındaki "merhûm Sultân Murâd Han" tabirinden bu tarihin en erken 1595 'in sonu olabileceği sonucuna varılabilir. Şu durumda Tadlîl ile bu risale arasında en az yirmi yıl var demektir. Bu yönüyle de risale olayın dolaylı muhatabidır.

Münîrî Efendi, Rusûhî ve gazeline Yûsuf Sinânüddîn kadar tahkir edici tarzda yaklaşmamıştır. Ancak onun Rusûhî̀yi "Şeyh Süleymân nâm-ı dalâl-nişân" sözleriyle tavsif etmesi ve söz konusu gazelin ya şairin kasdını aştığını yahut da sağdan soldan toplanan sözlerin taklit ve terkibiyle oluşturulduğunu dile getirmesi; Münîrînnin, Rusûhî ve meşhur gazelini tasvip etmediğinin bir göstergesidir. ${ }^{85}$ Risalenin şablonu basitçe şöyledir: I) Rusûhî̀nin mektubu II) Münîrîn nin gazeli şerh ü tevili III) Rusûhînnin iddialarının çürütülmesi. Münîrî-yi Belgradî tarafından gazel şöyle şerh ü tevil edilmiştir:

Evvelki beytün [Gizlü gencün lülü'-i lâlâsıyam / Şöhre-yi şehrem cihân kâlâsıyam]

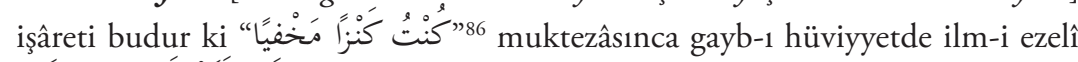

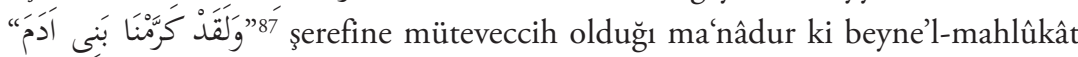

84 Münîrînin vefat yılı kesin olarak tesbit edilememiştir. Ancak bu tarihin h.1029 (1620) ile h.1038 (1628) arasında olduğu tahmin edilmektedir. Bkz. Taxhidin Bytyqi, "Balkanlarda Celvetîlik ve Münîrî-i Belgrâdî”, Azîz Mahmûd Hüdâyî: Uluslararası Sempozyum Bildirileri (20-22 Mayıs 2005), c. II, ed. Hasan Kâmil Yılmaz, (İstanbul: Üsküdar Belediye Başkanlığı), s. 230.

85 Münîrî, vr. 4b-5a.

86 "Ben gizli bir hazine idim.” Aclûnî, Kesfü̈l-Hafâ, II, 173 (2016).

87 “Gerçekten biz Adem oğlunu şerefli kıldık." İsrâ 70. 


\section{RUSÛHÎ'NİN KUS DİLİYLE BİR GAZELİ VE YÛSUF SINÂNNÜDDÎN İLE MÜNÎRÎ'NİN ŞAİRE REDDİYESI}

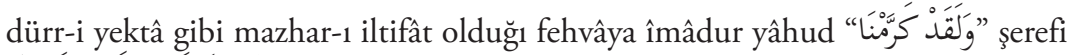
" zimnında gizlü genc olup Âdem ol gencün hulâsası ve vücûd-1 kâmili olduğına işâretdür (...) beyt-i sânî [Kıymetüm iki cihâna sı̆̆gmadı / Kulzüm-i 'şkun dür-i yektâsıyam] ehlullâh olduğı mertebeden işârdur " "وَّó ma'nâsından ihbârdur beyt-i sâlis [Trfl-ı ebcedhânum olmışdur melek / Bir güzeller müftisi monlâsıyam] hılâfet makâmına vâsıl

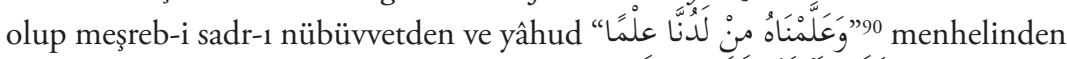

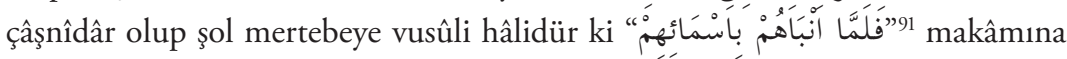
mâ-sadak olması misâlidür ammâ matla'un mısrấ-1 evvelün ma'nâ-yı evveline bu beyti sarf ensebdür dördinci beyti [Anamun karnında anam atası/ Oğlumun oğlın emer lâlâsıyam] merâtib-i tenezzülâta işâret olup nefs-i küll ve tabî‘at-1 külliyyeye 'akl-1 evvel ata makâmında olup ta'ayyün-i evvel ki ehadiyyet ve ta'ayyün-i sânî ki vâhidiyyet i'tibârıyıla 'akl-1 küll ve ehadiyyetden feyz alduğı ma'nâdan 'ibâretdür ve nâzım cihet-i câmi'de ikâmet olınup insân-ı kâmil makâmında olduğından ve anun ehli kılınduğından cihet-i kudsdan tecerrüdile müstefîz ve cihet-i ta'alluk ve beşeriyyetile tâliblere mufîz olmasından işầrdur (...)'abdun bidâyet-i hâline 'avdetden ihbârdur ki andan cem 'ü'l-cem' ile ta'bîr buyurmışlardur ve beyt-i hâmis [Mescid-i ‘şkun imâmı olmışam / Ehl-i deyrün hem çelîpâpâsıyam] 'ârif-i kâmil olup küfr ü îmân levni fark olınmaz sâhadan inhâ itmesidür (...) beyt-i sâdis [Her ne dirsem Hakk anı eyler hemân/ Şöyle benzer ben anun ăgasıyam] "فَذاذٍ diyü buyurilan hadîsün fehvâsıdur ağasiyum ol makâmun ehliyüm dimekdür beyt-i sâbi' [Ey Rusûhîşsem'-i cem'-i âlemün / Bâl u per yakmakda bî-pervâsıyam] fenâ fillâh olması menzilesinün ma'nâsıdur (...) bekâ billâh lâlâsıyum didügi 'ibâretden fehm olındı. ${ }^{93}$

Gazeli yukarıdaki şekilde açıklayan Münîrînnin Rusûhî ve gazeline dair tenkitleri ise şu şekildedir: Öncelikle Rusûhî matlaın Habîbullâh vasfinda diğer beyitlerin ise insân-1 kâmil hakkında olduğunu belirtmiştir. Lâkin şair gazeli kimin

88 "Şüphesiz ben sizin bilmediğiniz şeyi bilirim.” Bakara 30.

89 "Ehlullah üzerine dünya ve ahiret haramdır." Bu hadis Kesfül-Hafầda Deylemînin rivayetiyle şu

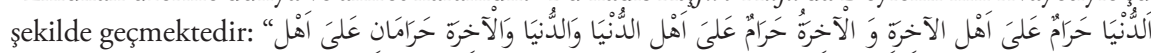

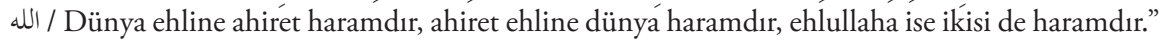
Aclûnî, Keş̧ül-Hafâ, I, 1314.

90 "Biz ona nezdimizden Rabbânî bir ilim öğretmiştik." Kehf 65.

91 "Vakta ki (Adem) onların isimlerini onlara haber verdi." Bakara 33.

92 "Bir kere kulumu sevince artık onun işiten kulağı [olurum.]" Nevevî, Riyâzü̉s-Sâlihîn Tercümesi, c. I, s. 363.

93 Münîrî, vr. 5a-6a. [Beyitler orijinal metne tarafımızdan eklenmiştir.] 
ağzından anlattığını belirtmediğinden ve gazelde birinci tekil şahıs eki kullandığından tavsif ettiği Habîbullâh ve gönderme yaptığı insân-1 kâmil kendisi olmaktadır. Bu durum üstü örtülebilecek bir kabahat değildir. Üstelik bu tarz kelâm ve teşbihler şairler arasında da revaçta değildir. Bir diğer nokta Rusûhînnin insân-1 kâmili anlatırken kullandığı kaba üslûptur. Şair bu bağlamda sanki insân-1 kâmili değil de bir tarrârı (yankesiciyi) tasvir ediyormuş gibi hareket etmiştir. Münîrî bu üslûbu "İnsân-1 kâmili kabîh elfâzıla ve fâsid ibârâtıla ta bîr idüp hikâyet itmek akbeh-i kabâyıhdan olduğı mukarrerdür (...) mahall-i niza' [kavga sebebi] olan şi r r gerek kendi hasb-i hâli olsun gerek mücerred kâli olsun nite kim kendi tasavvuf kâli olduğın tasrîh itmiş idi gerek vasf-1 hâl-i insân-1 kâmil olsun bu üslûba râh virilmeyüp inde'l-muhakkıkîn i'tibâr-1 fâsid ve ihtiyâr-1 kâsid olmış[dur]" sözleriyle tenkit etmektedir. Münîrî, Rusûhînnin bu teşbih ve ifade tarzını şeriat, ma'rifet ve hikmete muhalif; diyânete ise mugâyir bulur ve gazelin şeriata muhalefetinin çok açık olduğunu belirtir. Münîrîye göre bu gazel şu altı maddeden birine dahil edilebilir: 1) Müştebehü’l-mefhûmdur [ta'miye ve elgâz denen şifreli bir üslûba sahiptir] 2) Sûret-i şathdır [Şathiyedir] 3) Şu be-yi ilhâddır 4) Îmân nifâkıdır [Okuyanların imanlarını zayıflatır] 5) Şâ‘ibe-yi lehvdir [Faydasızdır, boş bir uğraşı̧ı] 6) Keşf-i sırdır [Sırlar alemine kapı aralamaktadır]. ${ }^{94}$

Gazelde kullanılan anlaşılmaz üslûp [ta'miye ve elgâz üslûbu] tıpkı Yûsuf Sinânüddîn gibi Münîrî tarafından da tenkit edilmiştir. Çünkü Münîrîye göre Rusûhî̀nin kelâmı hem anlaşılmazdır, hem de istikâmet üzere değildir. Kelâmın anlaşılır olmasıyla kastedilen lafzın manaya uygun çağrışımda bulunmasıdır. "Çünkü kelâmdaki asıl hedef sözü [ibareyi/cümleyi] anlamaktır. Anlaşılmayan söz ile hitap etmek hikmet sahibi olan zata yakışmaz." ${ }^{95}$ Bu bağlamda Rusûhî küfre kapı aralayan ta'miye ve elgâz üslûbu sebebiyle eleştiriyi hak etmektedir. Kelâmın istikâmet üzre oluşu ile risalede söz ve eylemin arasındaki uygunluk söz konusu edilmiştir. Münîrî, şairin fiiliyle (hâliyle) sözleri (kâli) arasında tutarsızlık olduğunu düşündüğünden, kelâmının da istikâmet üzere olmadığı fikrindedir. Aynen Yûsuf Sinânüddîn gibi, Münîrî de gerçek yüzleri maskeli bu mürşid takımının kendilerini eğri söz ve şiirleriyle ele verdiklerine inanmaktadır. Bu bağlamda Münîrî Efendi heterodoks sûfîlerle ulemâyı kıyasa tabi tutmaktadır:

94 Münîrî, vr. 6a-7a.

95 İbnü'l-Emîn Mahmud Esad, Fıkıh Usûlü: Telhis-u Usûl-i Fıkıh, nşr. Taha Alp vd., (İstanbul: Yasin Yayınevi, 2011), s. 107. 
“pes bu vech üzre didügi 'ulemâ-yı kışrî olmağa bunlar mı ehakdur yohsa müdde î kendi ve emsâli makûlesi kej-gûlar mı ehakdur bu bâbda 'ulemâ şerefiyile sûret-i salâhda geçinen tầife mâbeyninde fark katı zâhirdür (...) ehl-i 'ilm kısmı ne denlü fâsık olsa dîne halel virecek mahalle söz söylemez tahrîr itmez ammâ ol tầifede niçe kimse ne denlü zâhid ü 'âbid olsa dahı mahzâ benüm de 'irfânum varımış bilsünler diyü hẩil kelimât diyüp tahrîrlerinün ve şi 'rlerinün nihâyeti yokdur" ${ }^{\prime 6}$

Rusûhînnin arz-1 hâlindeki "Çivizâde" ve "sem"-i hümâyûn/sultân"a işaret de Münîrî tarafından ağır bir şekilde eleştirilmiştir. Münîrîye göre zendeka ve ilhâd mevzusunda bazı sûfilerin aleyhine fetvalar veren Çivizâde her ne kadar Rusûhî tarafından medh edilmiş gibi gözükse de aslında Rusûhî takiye yapmakta ve Çivizâde’yi zemmetmektedir. Sultana yapılan işaret ise III. Murâd (15741595)' 'n tasavvuf kelâmına ilgisi bilindiğinden, Rusûhî’nin sultanın gözüne girme çabası olarak yorumlanmıştır:

"nâzımun [Rusûhî̀nün] esâs-1 dîni atası gibi kavî didügi zâhirdür zîrâ merhûm Çivizâde Fusûsîler'ün küfrine fetvâ virüp ve Gülşenîler'ün ilhâdına dahı fetvâ virüp ve semâ‘ $u$ rakslarına muhkem dolaşduğı cihetile zamânında ve sonradan gelen sûfîlerün yanlarında sû'-i zann üzre vaz' u 'add olınup hakkında çok güft ü gû itmişlerdür nez'-i rûhda îmânın fulân 'azîz kurtarmışdur diyü yollarında gurûrlarından böyle çok ma nâ tefevvüh iderler nâzım tatlu dilile ol kıssaya telvîh idüp atası gibi kavî didügi[nden] murâd zemdür (...) merhûm Sultân Murâd tasavvuf-1 kâlîye mâyil olup nazm-1 merkûmı teveccühi [Rusûhînnin gazel(ler) ini okuması] cihetiyile 'arz-1 hâle cür'et idüp tâ’ife-yi mutasavvıfa mücâhede vü mükâşefelerinde vâkı' olan şübhelerin şeyhlerine 'arz eylemek mâ-takaddemden 'âdetleridür didügi sözi de yâ zikr olınan kabîldendür veyâ riyâ-yı sırf makûlesi hâlden nâşîür [riyası hâlinden anlaşılmaktadır]"

Münîrî̀nin, Rusûhîye yönelttiği eleştiriler dördüncü beyit için de sürmektedir. Zira Münîrîye göre Rusûhî bu beyitte tevazu yerine tekebbürü tercih ediyor, kendini lalalık makamına yerleştiriyor ve etrafa üst perdeden sesleniyor. Hatta kendisi bir yana, halifelerinin halifeleri dahi kabiliyette birçok piri terbiye edecek

96 Münîrî, vr. 8ab.

97 Münîrî, vr. 8ab. Çivizâde için bkz. Mehmet Gel, "XVI. Yüzyılın İlk Yarısında Osmanlı Toplumunun Dinî Meselelerine Muhalif Bir Yaklaşım: Şeyhülislam Çivizâde Muhyiddin Mehmed Efendi ve Fikirleri Üzerine Bir İnceleme”, (Yayımlanmamış Doktora Tezi), Ankara: Gazi Üniversitesi Sosyal Bilimler Enstitüsü, 2010. 
mertebede. Münîrîyi hiddetlendiren unsurlardan biri de Rusûhî̀ye edilen nasihat ve tövbe etmesi teklifinin şair tarafından dikkate alınmaması. Rusûhî tövbe etmek yerine kendisini savunuyor, nasihat edenleri de güneşi balçıkla sıvamakla itham ediyor. Gazelini güher, güneş ve hüsn-i Yûsufa benzeterek kabahatine kabahat ekliyor. ${ }^{98}$ Beşinci beyit ise Münîrî tarafından "mescid, ışıklar tekkesi ve kilise" arasında bocalayan bir kişinin hali olarak tasvir ediliyor. Münîrî, şairin bu tavrını "Onlar müminlerle kâfirler arasında bocalayıp dururlar; ne onlara bağlanırlar, ne de bunlara." (Nisa/143) ayetiyle açıklıyor. ${ }^{99}$

Neticede tıpkı Yûsuf Sinânüddîn Efendi gibi Münîrî de gazelin tüm beyitlerini ya teşbihlerdeki kabalıklar ya ilhâda kapı aralaması yahut da şairinin takındığı üslûp sebebiyle tenkit ediyor.

\section{Sonuç}

1. Rusûhînnin kimliğine dair farklı görüşler ileri sürülmüş, şair Emîr Osmân Hâş̧imî ve Mesnevî şarihi Rusûhî-yi Ankaravî ile karıştırılmıştır.

2. Rusûhî ile ilgili temel kaynak durumunda olan iki tezkirede şairin biyografisine dair tutarsızlıklar mevcuttur.

3. Genelde ulema-sûfî çekişmesi şeklinde görülen bu tür tartışmalar bu olay özelinde medrese kökenli iki sûfî [Rusûhî-Sinânüddîn] arasında tezahür etmiştir.

4. Rusûhî ile Sinânüddîn Efendi arasında gerçekleşen bu olayın temel kaynakları Rusûhîye ait bir gazel, gazelin tevil edildiği bir mektup, şairin kendini savunmak adına şeyhülislâmdan aldığını iddia ettiği bir fetva ve tüm bunları çürütmek amacıyla yazılmış bir risaledir.

5. Münîrî-yi Belgradî de Rusûhî ve iddiaları için bir risale yazmıştır. Münîrî, risalesinde Rusûhîyi ikiyüzlülükle suçlamış ve bu tür kişilerin sürekli çamur attıkları zahir ulemasından bin beter olduğunu vurgulamıştır. Zira ulemadan hiçbir şekilde mukaddesatı tahfif eden kelâm sâdır olmamışken bazı sûfîler bunu kendine meslek edinmiştir.

6. Rusûhînnin bu gazeli teşbihlerindeki lâubalilikler sebebiyle ciddi anlamda tenkide uğramış ve şairini de zor durumda bırakmıştır. Öyle ki Rusûhî bu olay neticesinde sürgün edilmiş yahut canını kurtarmak için firar etmek zorunda kalmıştır. Sonrasında ise Rusûhînnin akıbeti meçhuldür.

98 Münîrî, vr. 12b-13a.

99 Münîrî, vr. 13a. 
7. Rusûhînnin başına gelenler kazara söylenmiş bir gazel neticesinde değildir. Bu üslûpta şiirler söylemek şairin genel karakteridir. Yûsuf Sinânüddîn’e göre Rusûhî bu tarz şiirler söylemek ve neticesinde bunları tevil ederek hem saray hem de halk indinde prestij kazanma amacındadir.

8. Gazele tepkilere rağmen Rusûhînin acilen cezalandırılmaması o dönemde olaya çok da ehemmiyet verilmediğinin göstergesidir. Demektir ki Rusûhînnin son tahlilde başına gelenler gazelin çıkardığı kargaşadan ziyade Sünbüliyye şeyhinin gayretleri neticesinde olmuştur.

9. Birini şairin kendi mektubu ve diğerini ise Münîrî risalesinden okuduğumuza göre gazel en az iki farklı şekilde tevil edilebilmektedir. Ancak "gurura kapılmak" gibi şaire izafe edilen -çok da somut olmayan- sebeplerle Rusûhînnin mülhidlikle suçlanması olayın dinî hassasiyetlerden ziyade kişisel bir rekabet yahut hesaplaşmadan kaynaklanabileceğini hatıra getirmektedir. İhtimal ki Yûsuf Sinânüddîn bu hesaplaşmada gazeli bir silâh olarak kullanmaktadır. 


\section{EK: Rusûhî’nin Münîrî risalesinde kayıtlı mektubu}

Pâye-yi serîr-i 'âlem-masîrlerine inhâ-yı eviddâne dâ‘ î-yi hakîr oldur ki her kavmün mahsûs-1 i'tibârı münâzaraları 1stılâhları üzre cârîdür husûsâ kelimât-1 sûfiyye ki rumûz-1 hafiyye olup anlara hakîkat gayra mecâzdur sầir fünûndan

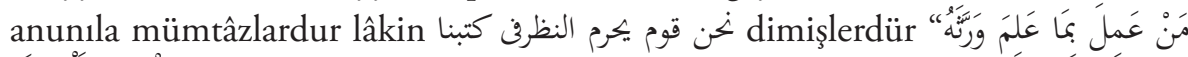
mekteb-hânesinde sebak almışlardur niçe mesẩil-i müşsikileyi bilmişlerdür ma'rifetleri bahrına her gavvâs âşnâ olmaz ve sehl-i basîretile her dîde rûşenâ bulmaz kesretde vahdetden mahrem-i ekall-i kalîl olur makâmında samem-i kemînde ârrız olur ekseri lâ-yefhem makâmında turur hattâ a'del-i ashâb Hazret-i Ömer bin el-Hattâb Resûl-i veliyyü’t-tevfîk Ebû Bekr-i Sıddîk Hazretleri ile ahyânen söyleşürleridi dinleridük ${ }^{101}$ gâh olur anlaridük gâh olur lafzını istimâ eyler ma'nâsını fehm itmezidük gâh olur elfâzını bile işitmezidük diyü buyururlarıdı anun içün ashâb-1 zâhirile erbâb-1 bâtın beynine tefrika düşüp sulehâ hakkında 'ulemâ üç firka olmışlar ezkiyâsı ['ul]ûm-1 şer'iyyeye mesâsı ve rüsûm-1 âliyye ile istînâsı olanları müsellem tutagelmişler ba'zıları kendü hâllerine komak eslem anlamışlar ammâ 'ulemâ-yı kışrî ve meşâyih-i kışrî الما جهل benüm emsâlüm ve küllî lübb-i lübbe vâsıl ehlullâha ta'n u dahl idüp kimi inkâr kimi ikfâr idegelmişler iken fi'l-hakîka yanılmışlardur mukallid kâmilü'lîmân muvahhid butlân üzre olmak el-hakk hakk degüldür ba'de zâlik bu devlethâh-1 sâlik-râh dahı nâşîden tahâşî idüp sadef-i dürer içre bir iki güher bahr-1 mescûrda mestûr itmiş idüm piloriler[i] har-mühre sanmışlar râygân buldukları içün alçak anlayup bâzâr-1 isầetde sarf-1 gıybeti bildükleri gibi almış satmışlar benüm yanumca niçe ekâbirün dürer-i nâ-süftelerini elmâs-1 'irzıla egri bügri delmişler hüsn-i Yûsufi máyûb [ile] güneşi balçığıla mahcûb itmişler câmi'-i rub'-1 meskûn pây-taht-1 sa âdet-meşhûnda ol Necefinnün gûş-1 şehden gayrı sadefi bulınmaduğı sebebden zevâhir-i te'vîlâtıla mülemma' ve cevâhir-i tevcîhâtıla murassa' eyleyüp sarrâf-1 müsellem müftî-yi âlem ve mertebe-yi ictihâda sadr-1 âmâdetü's-sudûr Rûmili Kâdî-askeri Kâdî-zâde ve esâs-1 dîni atası gibi kavî kâziyyu'l-kuzât Anatolı İbn Çivi Hazretlerinin meclis-i 'âlîlerine arz olınup bunlarun gibi simsârlar mi'yârlarında tamâmü'l-ayâr bulınduğından sonra gurer-i dîde-yi gam-dîdem gibi hâk-pây-1 şehr-yâra tekrâr îsâr olınmak lâzım geldi tâ ki sem'-i hümâyûn sû'-i zandan masûn olup dürer-i ma'delet-rehînlerinde sâlik-i

100 “Öğrendikleriyle amel edene Allah Teala bilmediklerini öğretir." Ebû Nuaym, Hilyetü’l-Evliyâ, $\mathrm{X}, 15$.

101 Çorum nüshasında "dinlerdük" yerine "anlarduk" yazılmış.

102 "Kişi bilmediğinin düşmanıdır." sözünün mucebince. 
râh-1 yakîn kuttâ‘-1 tarîkdan emîn olup safâ-yı hâtır ile menzil alup dergâh-1 'izzete vâsıl olup oldukda zikr-i cemîl sultân-1 âdil eyleye tầife-yi mutasavvıfa mücâhede vü mükâşefelerinde vâkı' olan şübhelerini şeyhlarına 'arz eylemek mâtakaddemden 'âdetleri olup anlar dahı tarîkların ağyârdan sıyânet ya'nî ehl olmayan müdde'îlerden himâyet eylemek ve ana göre tedbîr kılmak içün cevâblarını 'alâ-vechi mine'l-îcâz ve min-tarîkít-ta'miye ve'l-elgâz bir sahîh ma'nâya îmâ üzre 'ıkd idüp zâhirini bir niçe mefâsidi müvehhim mefhûma şâmil gösterüp lâkin her fâsid sûretün zımnında niçe fevâyid-i sahîha gizleyüp katllerine tahsîs ü tansîs gözlemek yanlarında emr-i ehemm olduğı cihetde[n] ben dahı bu'd-1 mesâfeden su'âl iden sâlike âdet-i me'lûfemüz üzre hıtâb eylemiş idüm hatâ anlamışlar sakat söylemişler galat eylemişler el-cevâb ehl-i sünnet ve cemâ'atdan olup niçe müddet meşâyih-i ızâma hıdmet eyleyüp efâli şer'-i kavîme muvâfakat üzre olan kimesnenün fi'li kavline delîl olup kelâmı te'vîl olınur inkâr belki mü’minün bir kavlinün cihât-1 kesîre ile küfre şumûli olup cihet-i vâhideden hakka tahammüli olsa ol bir vechile 'amel olınup vücûh-1 fâsideden ihmâl ile fetvâ virilür ikfâr olınmaz et-te'vîl pes nazm-1 mukaddimetü'l-irşâddan murâd "her ne dirsem Hakk anı" ya'nî oldur kim sözümi hemân eyler yánî mukârin bi’z-zamân eyler "şöyle benzer ki ben ânun" ya'nî sözüm mukârini olan zamânın ağası ya 'nî 'abd-1 hâssıyum ya'nî ol ânda mühim olan hâle mülâzimem tazyî'-i evkât eylemezem dimek olup sûfî ibnü'l-vakt gerekdür didükleri ma'nâdan 'ibâret ve ef âli mukayyed bi’z-zamân olanun imkânından kinâyetdür bu tefsîr ağa 'ibâretinden 'ubûdiyyet murâd olduğı takdîrcedür ve ağalarun elleri altında reâyâ olıgeldükleri i'tibârıla şeyh-1 bü'l-vakt yánî sâhib-i tasarruf olduğına binâ'en hılâfet-i ma'neviyyeye işâretdür nite kim üstindeki beytde imâm-1 İslâm ve râ'î-yi asnâm olmışam dimegile gavs-1 'âleme vezîr-i a'zam olduğını ibhâm eylemiş mâ-verâ-yı 'akldan ba'z sözler dahı söylemişler idi anlarun ma'nâları bilindi mi ki bunda ilendiler bilmem neden ilendiler el-hakk "pâs" dan "pâ"sı fark itmeyen fark-1 za îfetü'l-ecsâsun inkârlarına ulü'l-ebsâr ol kadar i'tibâr eylemezler ve ma'a-hâzâ pâd-şâh-1 'âlîcâhlarun sekbânları dahı "ağa"larıdur hıdmetlerinde olduğumuz fukarânun nefs-i emmârelerin[i] mürebbî olduğumuz i'tibârıla sekbân-1 Hudâ hîç olmazısa kendü nefsümüz kelbine kethudâ olduğumuzdan ibâretdür ve "her ne dirsem Hakk anı eyler" dimekden murâd ihtiyâr-1 cüz'îmüz her neye sarf eylersem Hak Teâlâ anı sarf eyleyüvirmek sünnetullâhdur dimek olup ehl-i sünnet ve cemâ'at mezhebine irşâddur ve yâhud kelâm-1 ma'hûddan erbâb-1 şuhûd mâhiyyât-1 gayr-1 mec ûle olmak beyne't-tầife şâyi' ve 'ilm ma'lûma tâbi' olup ma'lûmun âlimde eseri takrîr

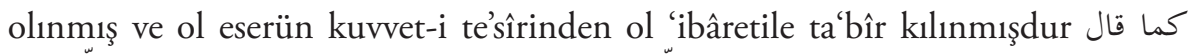
الشيخ و للمعلوم اثر في العالم فما علم الحق الآّ ما كان فن عين المعلوم فما حكم الله في الاشياء الآّما هم 
عليه و ما قدّر الاّ ما حكم و ما اراد الّاّ ما قدّر فهو العليم الحكيم القدير المقدّر المريد على حسب قابليته الممكن ve bi'l-cümle irâdet kadere kader kazâya kazâ 'ilme 'ilm ma 'lûma tâbi' olup isti 'dâd-1 ezeliyye âlimde hâkim olduğını irâdet içün ağa ibâretiyile ta 'bîr olınmış edât-1 teşbîh ile teveccüh kılınmışdur fî-nefsi'l-emr da'vâ-yı 'ubûdiyyet eyleyüp nihâyet-i havâsdan olmağıla iddiâ olınmışdur lisân-1 isti'dâd duâsı makbûl olduğına îmâ kılınmışdur beyt-i ma'mûr binâsı esâs üzre olmışdur mes'ele-yi Cebr bi'l-külliyye kaldırılmışdur ve 'ale'l-husûs bu nazmun matla' 1 Habîbullâh vasfinda tertîb olınmışdur mâ-tahtında tertîb olanlar insân-1 kâmil ağzından hikâyeten nakl olınup bir sırr-1 şerîfi hâmil olmışdur ki ol hadîs-i kudsî ve necvâ-yı ünsîde

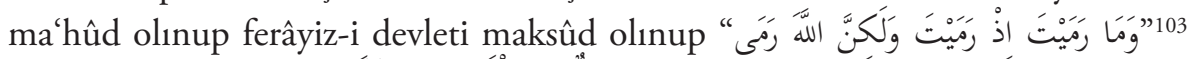

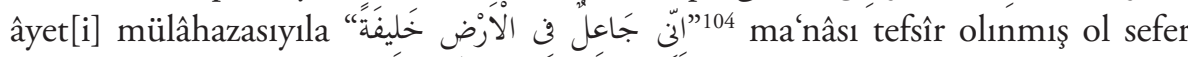
mezbûrda mezkûr olan "hakk" 'ibâreti kelâmun sıfatıdur anun zamîri kầilün şeyhinden kinâyet olınup şeyhun hakka kemâl-i mutâva'atından 'ibâret ve şeyhi yanında sözinün nüfûzına işâretdür ve bu mezkûrât tasavvuf kâlidür hâli degüldür yanılmazsam kầili hâli gibi ammâ tâ‘in [ayıplayan] yâ câhildür yâ gâfil beyt-i bâlâda mestûr zâhire muhâkemeleri bildüklerine göredür bunun birle Cüneyd ve Bâyezîd ve sâyir ehl-i tevhîd niçe bunun gibi kelâm söyleyüp mat'an-1 avâm-1 ervâm u a'câm olıgelmişlerdür erenler meydânda öndül alıgelmişdür 'ammâ dahı

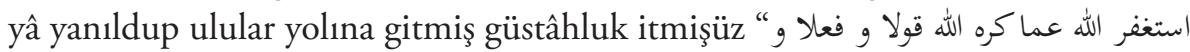
[beyt]

\section{Hudâ-yı cihanrâ hezâran sipâs \\ Ki gevher sipurdem begevher-şinâs ${ }^{106}$}

diyü nâzım arz-1 hâlün ihtitâmın böyle dimiş ve’s-selâm. ${ }^{107}$

103 “(Ey Resûlüm), attığın vakit sen atmadın, lâkin Allah attı.” Enfâl 17.

104 "Ben yeryüzünde bir halife yaratacağım.” Bakara 30.

105 Sözle, fiille, düşünceyle, bakışla Allah’ın mekrûh kıldığı şeyleri yapmış olmaktan istiğfâr eylerim. Ve ona tevbe eylerim ve ondan tevbemin kabulünü ve mağfiret etmesini dilerim. Şüphesiz o çok bağışlayıcıdır ve tevbeleri çok kabul edendir.

106 Hakk’a binlerce kere şükürler olsun ki gevherin kadrini bilenler için gevher çıkardım.

107 Münîrî, vr. 1b-4b. 


\section{RUSÛHÎ'NİN KUŞ DİLIYLE BİR GAZELİ VE YÛSUF SİNÂNÜDDÎN İLE MÜNÎRI'NİN ŞAİRE REDDİYESI}

\section{Rusûhî̀nin Kuş Diliyle Bir Gazeli ve Yûsuf Sinânüddîn ile Münîrînin Şaire Reddiyesi}

Öz —Sûfî şair Rusûhî hüner gösterme, itibar elde etme ve ilm ü irfanını ispatlama gibi gayelerle kuş dili üslûbuyla bir gazel yazar. Bu gazel zahiren dinî akidelere aykırı göründüğünden etrafta büyük firtınalar koparır. Rusûhî bu sebeple mülhidlikle suçlanır ve tövbeye davet edilir. Ancak geri adım atmaz ve üstelik şiirini savunan bir mektup kaleme alır. Mektubunda asıl hatanın kendisinde değil her şeyi zahirine göre yorumlayan ulemada olduğunu iddia eder. Bunun üzerine Rusûhî etraftan tepki görür. Hak ettiği cezayı çekmesi için kendisi gibi sûfî olan Yûsuf Sinânüddîn tarafından Rusûhîye bir reddiye yazılır. Reddiye ile şairin kendini müdafaa ettiği mektup ve patırtıya neden olan gazel yerden yere vurulur. Olay sıcaklığını kaybettikten sonra Rusûhî̀ye bir reddiye de Münîrî tarafından yazılır. Münîrî Efendi bu risalesinde öncelikle Rusûhînnin kendini savunduğu ve gazelini tevil ettiği mektubun metnini sunar, ikinci olarak gazeli şerh ü tevil eder ve son olarak da sûfî şairin iddialarını çürütmeye çalışır.

Bu çalışma bir gazelin tetiklediği hesaplaşmaya yakından tanıklık edebilme niyetiyle kaleme alınmıştır.

Anahtar kelimeler: Tadlîlüt-Tẻvîl, Rusûhî Süleymân, Yûsuf Sinânüddîn, Münîrî-yi Belgradî, gazel, mektup, zendeka ve ilhâd

\section{Kaynaklar}

\section{Yayınlanm»s Eserler}

Algar, Hamid: Nakşibendîlik, İstanbul: İnsan Yayınları, 2012.

Aşık Çelebi: Meşẩirü̉ş-Şu'arâ, c. III, nşr. Filiz Kılıç, İstanbul: İstanbul Araştırmaları Enstitüsü, 2010.

Bursalı Mehmed Tahir: Osmanlı Müellifleri, c. II, nşr. Cemal Kurnaz-Mustafa Tatcı, Ankara: Bizim Büro Yayınları, 2009.

Cebecioğlu, Ethem: Tasavvuf Terimleri ve Deyimleri Sözlüğ̈̈, İstanbul: Ağaç Yayınları, 2009.

Ebû Zekeriyyâ Muhyiddîn Yahyâ İbn Şeref en-Nevevî: Riyâzüs-Sâlihîn Tercemesi, terc: Salih Uçan, İstanbul: Arslan Yayınları, 1989.

Ertem, Rekin: Yahyâ Divanı, Ankara: Akçağ Yayınları, 1995.

Erünsal, İsmail E.: XV-XVI. Asır Bayrâmî-Melâmîliğinin Kaynaklarından Abdurrahman El-Askerî̀nin Mir'âtü'l-Işkı, Ankara: Türk Tarih Kurumu Yayınları, 2003.

Gölpınarlı, Abdülbaki: Melâmîlik ve Melâmîler, 5 Baskı, İstanbul: Milenyum Yayınları, 2013. 


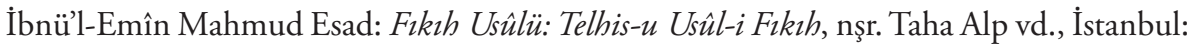
Yasin Yayınevi, 2011.

Kadı İyaz: Şifa-i Şerif, terc. Naim Erdoğan-Hüseyin S. Erdoğan, İstanbul: Çile Yayınları, 1977.

Kınalızâde Hasan Çelebi: Tezkiretüşs-Şuarâ, c. I., nşr. İbrahim Kutluk, Ankara: TTK Basımevi, 1989.

Konuk, Ahmed Avni: Fusûsu'l-Hikem Tercüme ve Şerhi, c. I, nşr. M. Tahralı - S. Eraydın, İstanbul: Marmara Ü. İlahiyat Fak. Vakfı Yayınları, 2005.

Latîfi: Tezkiretüş-Şuarâ ve Tabsıratün-Nuzamâ, nşr. Rıdvan Canım, Ankara: Atatürk Kültür Merkezi Başkanlığı, 2000.

Mecdî Mehmed Efendi: Hadâiku’ş-Şakâyık, nşr. Abdülkadir Özcan, İstanbul: Çağrı Yayınları, 1989.

Ocak, Ahmet Yaşar: Osmanlı Toplumunda Zındıklar ve Mülhidler, (15-17. Yüzyıllar), 4. Baskı, İstanbul: Tarih Vakfı Yurt Yayınları, 2013.

Onay, Ahmet Talat: Eski Türk Edebiyatında Mazmunlar, nşr. Cemal Kurnaz, İstanbul: Milli Eğitim Bakanlığı Yayınları, 1996.

Osmanzâde Hüseyin Vassâf: Sefine-i Evliyâ, c. II, nşr. Mehmet Akkuş-Ali Yılmaz, İstanbul: Kitabevi, 2011.

Öngören, Reşat: Osmanlilar'da Tasavvuf: Anadolu'da Sûfîler, Devlet ve Ulemâ (XVI. Yüzyll), 3. Baskı, İstanbul: İz Yayıncilık, 2012.

Özköse, Kadir: “İbnü’l-Vakt ya da Ebu'l-Vakt Olabilmek”, Sûfî Perspektif, 64, 2006, ss. 22-25.

Pervâne b. Abdullâh; Pervâne Bey Mecmuası, c. 3, nşr. Kamil Ali Gıynaş, İstanbul: Akademik Kitaplar, 2014.

Sühreverdî: Tasavvufun Esasları: Avârifü'l-Meârif Tercemesi, nşr. H. Kâmil Yılmaz-İ̀fan Gündüz, İstanbul: Vefa Yayıncilık, 1990.

Şentürk, Ahmet Atilla: Klasik Osmanlı Edebiyatı Tiplerinden Sûfî yahut Zâhid Hakkında, İstanbul: Enderun Kitabevi, 1996.

Taxhidin Bytyqi, "Balkanlarda Celvetîlik ve Münîrî-i Belgrâdî", Azîz Mahmûd Hüdâyî: Uluslararası Sempozyum Bildirileri (20-22 Mayıs 2005), c. II, ed. Hasan Kâmil Yılmaz, İstanbul: Üsküdar Belediye Başkanlığı, ss. 219-238.

Velikahyaoğlu, Nazif: Sümbüliyye Tarikatı ve Kocamustafapaşa Külliyesi, İstanbul: Çağrı Yayınları, 2000.

Yurdaydın, Hüseyin G.: "Düşünce ve Bilim Tarihi (1600-1839)” Türkiye Tarihi 3: Osmanl Devleti (1600-1908), İstanbul: Cem Yayınevi, 1997, ss. 275-341.

Yücer, Hür Mahmud: "Sünbüliyye”, TDV İslâm Ansiklopedisi, c. 38, İstanbul 2010, ss.136140. 
RUSÛHÎ'NİN KUS DİLİYLE BİR GAZELİ VE

YÛSUF SİNÂNÜDDÎN İLE MÜNÎRI'NİN ŞAİRE REDDİYESİ

\section{Arşiv Belgeleri}

Âşık Çelebi, Tezkire-yi Şu'arâ, Çorum Hasan Paşa İl Halk Ktp., 19 Hk 1964, vr. 332a.

La'lî Şermî en-Nakşbendî, Şerh-i Nutk-ı Hazret-i İdrîs-i Muhtefî, Milli Ktp. 06 Mil Yz B 169 , vr. $1 b-8 a$.

Mehmed Amîkî, Risâle-i Tầife-i Melâhidân, Milli Ktp, 06 Mil Yz A 330/3, vr. 60a-70b.

Münîrî-yi Belgradî, Şerh-i Gazel-i Rusûhî, Milli Ktp, 06 Mil Yz A 2927/10, vr. 164b-167a.

Münîrî-yi Belgradî, Şerh-i Kaside-i Süleyman, Çorum Hasan Paşa İl Halk Ktp. 19 Hk 668/1(a), vr. 1b-34a.

Nadazlı Menkabesidür, İBB Atatürk Ktp., Osman Ergin, nr. 832, vr. 59b-60a.

Rusûhî Süleymân, Risâle fî-Hakkir-Revâfiz, Milli Ktp., 06 Mil Yz A 5221/3, vr. 54a-55b.

Şerh-i Kasîde-yi Rusûhî, Milli Ktp., 06 Mil Yz A 2581, vr. 148a-153b.

Yûsuf Sinânüddîn, Tadlîlü't-Tèvîl, Manisa İl Halk Ktp., 45 Hk 2912/8, vr. 111b-120a.

Yûsuf Sinânüddîn, Tadlîlü't-Têvîll, Süleymaniye Ktp., Esad Ef. nu. 3689, vr. 1b-9a.

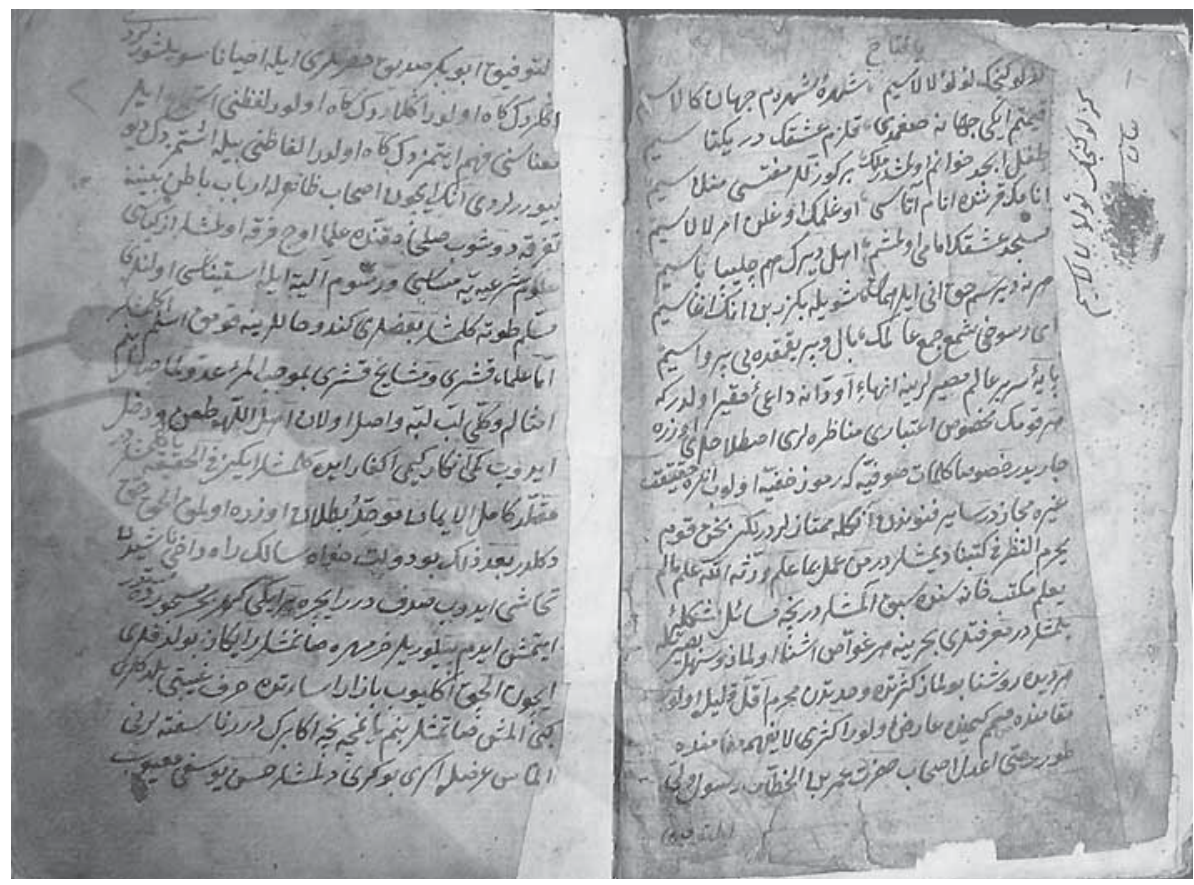

Münîrî-yi Belgradî risalesi (Çorum nüshası 1b-2a)

[Rusûhî̀nin reddiyeye uğrayan gazeli ve mektubu] 